\title{
Sexuality and Nationalism: The Impact of Sexual Regimes on Gay and Lesbian Belonging
}

\author{
by \\ Oren Howlett (B.A. Hons) \\ A thesis submitted to the Faculty of \\ Graduate Studies and Research in partial fulfilment \\ of the requirements for the degree of \\ Masters of Arts in \\ Canadian Studies
}

Carleton University

Ottawa, Ontario

August 17, 2005

(C) 2005 


$\begin{array}{ll}\begin{array}{l}\text { Library and } \\ \text { Archives Canada }\end{array} & \begin{array}{l}\text { Bibliothèque et } \\ \text { Archives Canada }\end{array} \\ \begin{array}{l}\text { Published Heritage } \\ \text { Branch }\end{array} & \begin{array}{l}\text { Direction du } \\ \text { Patrimoine de l'édition }\end{array} \\ \begin{array}{l}\text { 395 Wellington Street } \\ \text { Ottawa ON K1A ON4 }\end{array} & \begin{array}{l}\text { 395, rue Wellington } \\ \text { Ottawa ON K1A ON4 } \\ \text { Canada }\end{array}\end{array}$

Your file Votre référence

ISBN: 0-494-10050-8

Ourfile Notre référence

ISBN: 0-494-10050-8

NOTICE:

The author has granted a nonexclusive license allowing Library and Archives Canada to reproduce, publish, archive, preserve, conserve, communicate to the public by telecommunication or on the Internet, loan, distribute and sell theses worldwide, for commercial or noncommercial purposes, in microform, paper, electronic and/or any other formats.

The author retains copyright ownership and moral rights in this thesis. Neither the thesis nor substantial extracts from it may be printed or otherwise reproduced without the author's permission.
AVIS:

L'auteur a accordé une licence non exclusive permettant à la Bibliothèque et Archives Canada de reproduire, publier, archiver, sauvegarder, conserver, transmettre au public par télécommunication ou par l'Internet, prêter, distribuer et vendre des thèses partout dans le monde, à des fins commerciales ou autres, sur support microforme, papier, électronique et/ou autres formats.

L'auteur conserve la propriété du droit d'auteur et des droits moraux qui protège cette thèse. $\mathrm{Ni}$ la thèse ni des extraits substantiels de celle-ci ne doivent être imprimés ou autrement reproduits sans son autorisation.
In compliance with the Canadian

Privacy Act some supporting forms may have been removed from this thesis.

While these forms may be included in the document page count, their removal does not represent any loss of content from the thesis.
Conformément à la loi canadienne sur la protection de la vie privée, quelques formulaires secondaires ont été enlevés de cette thèse.

Bien que ces formulaires aient inclus dans la pagination, il n'y aura aucun contenu manquant.

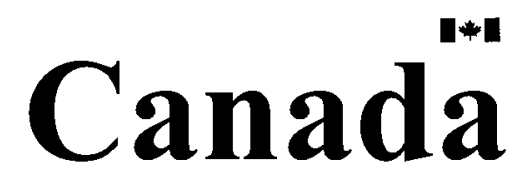


For all those who struggle for belonging and acceptance that moves beyond tolerance 


\begin{abstract}
The relationship between nationalism and sexuality is rarely studied. This thesis addresses this lacuna within the Canadian context and explores of the relationship between English Canadian civic nationalism and homosexuality. I argue that the role of nationalism in the exclusion of gays and lesbians must be acknowledged. As such, I contend that English Canadian civic nationalism is an exclusionary force that denies gays and lesbians equality and belonging. I then suggest this process of exclusion occurs through sexual regimes which create and reproduce a compulsory heterosexuality within the English Canadian nation. To demonstrate the existence and operation of sexual regimes, I offer a theoretical framework that accounts for sexual regimes' exclusion of gays and lesbians. I then provide a survey of Canada's three distinct sexual regimes and explore the incomplete deconstruction of the third sexual regime with a snapshot analysis of the same-sex marriage debates.
\end{abstract}




\section{Acknowledgments}

This thesis marks the end of a three year journey that began in Political Science and ended in Canadian Studies. Consequently, there are many people I must acknowledge for their support and love. First, I have to thank Rheneval Linford Howlett - my father, my inspiration, and reason I continue to pursue my dreams. You gave me all the life skills and tools I needed to carry on after your death. Thank you for raising me to be the strong man I am today. I love you. I would like to thank the Baranski family - Richard, Nona, Stefan and Monica - and the Medina-Kramer family - John, Theresa, Sarah, Timothy, Sarah and Adrian. You opened your homes and hearts to me. For that, I am thankful. Your support and love continue to sustain me through the toughest times in my life. Thank you for everything.

I would have never completed this thesis without the best thesis supervisor in the world, Pauline Rankin! Thank you for teaching me the value of verbs, the importance of reading, and the necessity of communicating in a clear, crisp, and concise manner. If I am a better academic, it is because of you, your strategic thinking, and infectious laughter. To say that you are a mentor is an understatement, I truly consider you to be a dear friend. Thank you so much for everything.

I am greatly indebted to Professor Jill Vickers. Her work has been a source of inspiration and shaped the way I think of the world and nationalism. Thank you so much for your research, wise counsel, and patience. I hope that this thesis does your contribution to academia's understanding of nationalism justice.

As I complete this chapter of my academic career, I would also like to acknowledge the faculty and staff at the School of Canadian Studies. Thanks to Richard Nimijean for bringing me back to the Canadian Studies fold and for being so supportive throughout my three years at Carleton. I am also grateful to both Mary Casaubon and Cathy Schmueck for their administrative support and words of encouragement throughout this thesis process. I appreciate the skill, expertise, knowledge, and interest that you both gave to me and so many others before me. Thank you both for being so wonderful!

Finally, I would like to thank my friends and colleagues. These are the people with whom I shared, whined, and laughed during this long, arduous thesis writing process. Shafik Kamani and Terence Go - You boys are my soul brothers! I thank you for checking in on me and making sure I kept at it. Amy Hoffman, Valery Navrette, Melanie Ching, Julie Coultas, Nicola Cameron, Nadia Theodore, Maghan Stewart and Annie Turner - You are all phenomenal women! Thank you for your support and listening ears. The Corporate Performance, Evaluation, and Audit Division at the Social Sciences and Humanities Research Council - Thank you all for your understanding and patience. 


\section{Table of Contents}

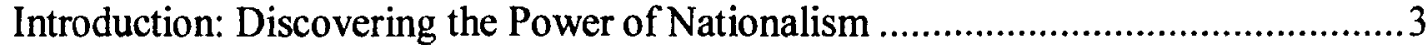

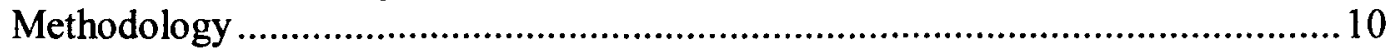

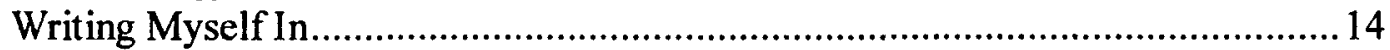

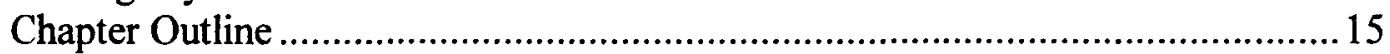

Chapter 2: Unearthing Sexual Regimes ...................................................... 18

Introduction: Defining Civic Nationalism ............................................... 18

Challenging the Concept of Civic Nationalism ..............................................20

Practically Speaking: Exploring Exclusions in Canada .................................25

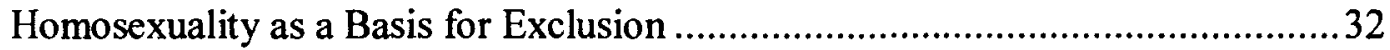

Building a Theoretical Framework: Sexual Regimes......................................... 36

Conclusion .........................................................................................4 40

Chapter 3: An Overview of Canada's Sexual Regimes ...................................... 42

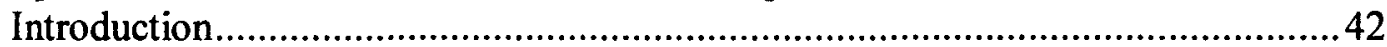

The First Sexual Regime: The Colonial Implementation of Regulation................44

The Second Sexual Regime: Enforcing National Security.................................48

The Third Sexual Regime: Gaining Managed Integration ..............................55

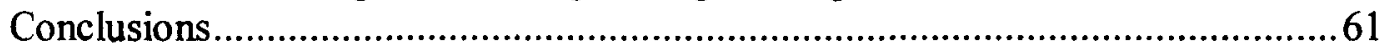

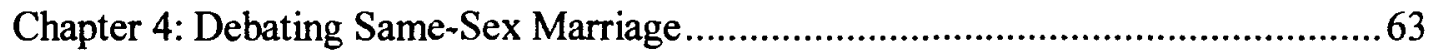

Introduction..................................................................................6. 63

Fighting the Long Fight: Searching for Relationship Recognition......................65

They're Just Not the Same: Families, Marriage and Homosexual Deviance ......... 70

Arguing Against Same-sex Marriage: Courts, Rights, and Mitigating the Effects of

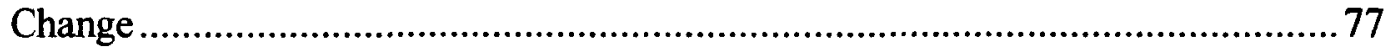

Love is Love: Talking Rights and Canadian Values........................................83

Resignation and Compromise: Reconciling Canadian Tensions .........................89

Conclusions......................................................................................... 94

Chapter 5: Interpreting Contestation: Same-Sex Marriage Debates........................97

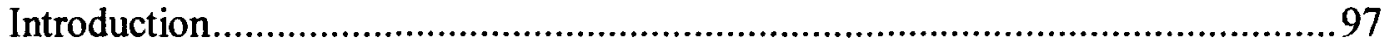

$(\mathrm{Re}$-)Defining the Character of Civic Nationalism ...........................................98

Reading the Contestation in the Same-sex Marriage Debates............................ 100

The Societal Costs of Deconstruction .......................................................... 105

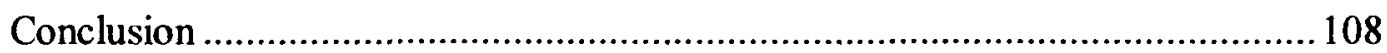

Conclusion: Gay and Lesbian Inclusion and Sexual Regimes .......................... 110

Overview of the Study ........................................................................ 110

Key findings of the Study .................................................................... 112

Limitations of this Study ................................................................. 115

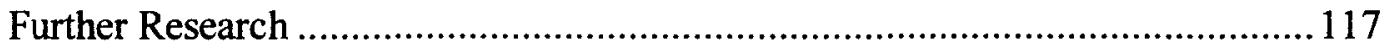

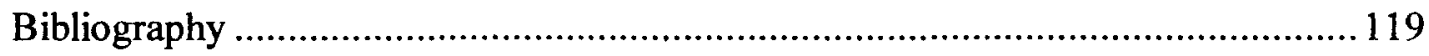




\section{Introduction: Discovering the Power of Nationalism}

Once sexual orientation is accepted as an illegitimate basis of discrimination and recognized as a legal, political, and cultural identity worthy of protection, then the definition of citizenship (and correspondingly the composition of the nation) broadens and deepens along sexual lines (Stychin, 1995, 103).

The relationship between nationalism and sexuality is rarely studied. Instead, scholars tend to focus on the two subjects as separate fields of inquiry. In commenting on existing works by Mosse (1985) and Parker et al. (1992) that treat both nationalism and sexuality, sociologist Sam Pryke observes that these works too lack a clear definition of the complex relationship between the two phenomena $(1998,531)$. Moreover, Pryke laments that their conceptual looseness leaves the relationship between nationalism and sexuality vague and intriguing $(1998,534)$.

My thesis responds to Pryke's call for definitional clarity and detailed "analysis of the importance of sexuality in certain key historical antagonisms..." $(1998,543)$. The purpose of this thesis is to explore the relationship between English Canadian civic nationalism ${ }^{1}$ and sexuality. To date, the bulk of scholarly research on the struggles of gay and lesbian ${ }^{2}$ Canadians attempts to document the slow acceptance of homosexuality

\footnotetext{
'For the purpose of this thesis, I focus only on English Canadian civic nationalism. I make this distinction in recognition of Quebec's nationalism which is quite inclusive of gays and lesbians. As widely documented, Quebec's nationalist movement involved many gay and lesbian individuals, who took central roles from the outset of the nationalist project (Rayside, 1998; Smith, 1998, 1999; Stychin, 1995, 1997; Vacante, 2005; Warner, 2002). As with feminism, attitudes towards homosexuality within the Quebec nationalist movements were largely inclusive. In fact, these movements were seen as allied. As a result, these influential gays and lesbians, like feminists, won legislative protections against discrimination, inclusion, and belonging within Quebecois society. This inclusion of gay and lesbian Quebecers within their national community is rare and has yet to be matched in English Canada, where, as I will argue, social marginalization and discrimination against gays and lesbians persists to this day. For a more recent treatment of the relationship between nationalism and sexuality in Quebec, consult Vacante, 2005.

${ }^{2} \mathrm{I}$ am limiting this study to Canadian gays and lesbians. This limitation is not meant to negate or minimize the exclusion of bisexual, transgendered, transsexual, two-spirited, inter-sexed, queer, or queeridentified individuals. In fact, as I will argue, the exclusion of all these groups occurs through the same sexual regime structure that seeks to maintain a heterosexual citizenry to the exclusion of all other sexual
} 
across Canada. One common hypothesis found in this body of work presumes that gay and lesbian acceptance will occur once homosexuality is a legally protected ground upon which discrimination will not be tolerated (Smith, 1998, 1999; Stychin, 1995, 1998; Warner, 2002). The assumption that state-granted legal rights will lead necessarily to belonging within Canadian society has had an overwhelming impact on the mobilization and activism of gay and lesbian communities.

At the same time, the continued discrimination of gays and lesbians in spite of numerous rights gains and equality-seeking campaigns raises suspicion with regards to this hypothesis. As Rankin observes, one must question "whether legal guarantees can transform assumptions about belonging and identity within the Canadian nation..." $(2000,184)$. In posing this question, Rankin raises the prospect of another factor that may account for the continued exclusion of gay and lesbian Canadians. It is my contention that a key factor missing in Canadian equality and rights seeking frameworks and scholarly literature on gay and lesbian mobilization is the failure to acknowledge the role of nationalism in maintaining a heterosexual nation-state.

My project attempts to reveal not only the nature of the relationship between what I identify as heterosexist nationalism and the English Canadian nation, but asserts that nationalism contributes to the denial of equality and belonging gays and lesbians seek to achieve through rights. In other words, the main argument of this thesis is that the exclusionary tendencies of English Canada's heterosexist nationalism and its nationstate perpetuates gay and lesbian exclusion from the English Canadian national

orientations - gay, bi or otherwise. Rather, it is for ease of analysis and with the acknowledgement of the complexities of the diverse sexualities which exist in Canada among its citizens that gays and lesbians are chosen as the main subjects of this project. 
community, despite the extension of legal rights. I posit that the faith that many gays and lesbians have in equality gained through rights, which will then translate into societal belonging, is perhaps misguided and requires an analytical approach that takes into account the power of heterosexist nationalism. My focus on nationalism and its discriminatory impact vis-à-vis gays and lesbians presents an alternative understanding of social inclusion and contestation within current Canadian debates around homosexuality. My perception of English Canadian civic nationalism is informed by the knowledge that nationalisms and nation-states have within them tendencies towards inclusion and exclusion (Jenkins and Sofos, 1996, 2). Certainly, the situation of gays and lesbians within the English Canadian nation over time has not been static and the gradual extension of legal rights has improved the lives of these communities and made some space for gay and lesbian citizens within the English Canadian nation. In this thesis, however, I focus specifically on the ongoing exclusionary tendencies of English Canadian civic nationalism so that I may expose the importance of theorizing nationalism from a minority perspective to make clear how civic nationalism can continue to marginalize minority communities.

To date, the majority of Canadian scholarly work by gay and lesbian academics emphasizes the struggles for gay and lesbian equality and the accumulation of rights won through the judicial system. The canon literature on Canadian gay and lesbian social movements focuses almost exclusively on the accumulation and extension of equality rights through legal action and legislative avenues. Here, scholars concentrate on activism for and against equality rights that attempts to influence parliamentary action and the passage of laws meant to secure equality for gays and lesbians (Adam, 
1999; Kinsman, 1996; Rayside, 1998; Smith, 1998, 1999, 2004). A second body of gay and lesbian movement literature adopts a case study approach to equality rights activism and examines the legal history of decisions made by various levels of the Canadian judiciary (Herman, 1994; Herman and Stychin, 1995; Lahey, 1999; Lahey and Alderson, 2004; MacDougall, 1999; Mazur, 2002; Stychin, 1998).

Yet, the attention given to rights and equality-seeking frameworks does little to account for the continued discrimination and inequality that gays and lesbians face in their everyday lives within Canadian society. Instead, what this body of research accomplishes is a crucial scholarly analysis of past movement struggles and corrective actions taken by the courts and government. While integral to the documentation of gay and lesbian legal history, I contend that this literature fails to account adequately for the slow transfer and codification of rights by Canadian political institutions. To better account for this phenomenon, I suggest a broader theoretical approach which allows for a nuanced analysis of the overlapping systems of oppression that deny gays and lesbians equality and acceptance into national communities. Using such a framework, one would be better able to understand the complexity of obstacles on the road to equality and establish tactics to realize this elusive goal.

By highlighting the inability of a rights-based or equality framework to respond adequately to questions of ongoing gay and lesbian marginalization, I do not wish to belittle this approach. As conceived, my project does not question at all the essential role of rights and equality-seeking as a strategic approach. Rather, by examining nationalism, I propose to address the question of whether "belonging" for gay and lesbian Canadians ultimately can be achieved through rights struggles. By adopting a 
more nuanced approach to analysing social contestation, the role of nationalism, which is often ignored as part of the battle in achieving inclusion within the national community, is finally taken into account.

Therefore, my central argument is that the social exclusion still experienced by Canadian gays and lesbians can be attributed in part to our civic English Canadian nationalism. English Canadian nationalism, I believe, maintains a narrow "morally acceptable" national (hetero)sexuality among its citizenry through what I label "sexual regimes." These sexual regimes, a term inspired by the race regime framework developed by Jill Vickers (2000), create and sustain a climate in which heterosexuality is sanctioned, rewarded, and accepted as the hegemonic national sexuality by those included within the national community. I contend that sexual regimes existed in North America before the Canadian nation-state was founded and continue to operate to this very day, excluding gays and lesbians from the "morally acceptable" heterosexual national community. As a result, $I$ believe that such sexual regimes continue to derive and exert their force from and within both the nation-state and its society.

To demonstrate English Canadian nationalism's ongoing exclusionary stance towards gays and lesbians through sexual regimes, I offer a case study of the same-sex marriage debates to illustrate the contestation of gay and lesbian inclusion within the national community. As I outline in my methodology section, my case study probes the universe of political discourse around sexuality within which debates on same-sex marriage unfold. This concept, coined by Jane Jenson (1989), is defined as "a space in which socially-constructed identities emerge in a discursive struggle" (238). For my purposes, I highlight debates from newspapers, online sources, and other written 
materials that utilize nationalism to encourage popular support for, or opposition to, the issue. In other words, I analyze the way nationalism is deployed by key gay and lesbian activists/groups, Canadian parliamentarians, and other opposing actors to support their position as to why gays and lesbians should have, or be denied, equality in marriage.

On July 20, 2005, Bill C-38: the Civil Marriage Act, received royal assent. With the passage of this legislation, Canada became the fourth jurisdiction in the world to officially recognize same-sex marriages. ${ }^{3}$ Although it appears that the English Canadian sexual regime now allows for the inclusion and recognition of same-sex couples, I remain sceptical concerning homosexual inclusion and argue that gays and lesbians in Canada will not experience the national belonging envisioned by activists and scholars despite the passage of this important law. I contend that while those gays and lesbians who conform to heterosexual relationship models and values may be granted partial belonging within Canadian society, those who continue to portray and publicly practice a non-conformist homosexuality will continue to experience social marginalization, despite legal protections. The source of this exclusion, I argue, is English Canadian nationalism and the incomplete deconstruction of sexual regimes.

My understanding of "belonging" as employed within this study derives from my personal experience within the English Canadian national community. My usage of "equality", "belonging", "inclusion" and "exclusion" deviate from accepted, everyday definitions. For me, belonging and acceptance require a nuanced understanding of our shared need to be fully embraced within the national community, without qualification

\footnotetext{
${ }^{3}$ Three jurisdictions recognized same-sex marriage/unions before Canada. The Netherlands granted same-sex marriage April 1, 2001. In Belgium, civil marriage was extended to gays and lesbians in June 2003. Most recently, Spain permitted the marriage of gays and lesbians on June 30, 2005. The law came into effect July 3, 2005.
} 
or condition. This acknowledgement then gives one the freedom to live their lives as valued, wanted, included contributors to and within a national community free from stereotypical judgements, discrimination, or categorization by both the nation-state and their fellow members of society. Equality is integral to this perception of belonging. I believe that the extension of equality, however, must be free of any distinctions and recognize the person as an included, contributing individual within society. As defined, therefore, my approach to belonging depends upon a foundational shift that refutes categorization and defines citizens simply as human beings struggling to better our national community.

In the case of same-sex marriage, for example, the ongoing categorization of "same-sex" marriage in popular discourse, despite the legislation's "civil marriage" moniker, does not signal acceptance or belonging. In contrast, I define acceptance as the designation of marriage within social, political and legal realms as the union of any relationship between two consenting individuals. Only the expansion of definitions without characterizations based upon identity signifies a true transformation of the nation's foundations. Such a shift is contingent, however, upon both society and the state. Action by one does not constitute acceptance, for the other may continue to exclude and marginalize. The failure of popular discourse to drop language that continues to segregate gays and lesbians and highlight distinctions between "heterosexual" versus "same-sex" marriage, therefore, reveals the extent to which gays and lesbians still remain just outside the English Canadian national community. 


\section{Methodology}

For the purposes of my snapshot case study on same-sex marriage, the debates explored in my discussion are considered to form part of the universe of political discourse around sexuality in Canada. The universe of political discourse is "a space in which socially-constructed identities emerge in a discursive struggle" (Jenson, 1989, 238). Jane Jenson's use of the universe of political discourse creates room for a critical understanding of how actors with various collective identities continually struggle for legitimacy and attention within this shared space $(1989,238)$. At issue in my thesis is the reproduction and representation of difference. Key actors within the debate over same-sex marriage, both within the state and outside of it, constructed their arguments in accordance with their view of the world in order to support their positions for or against same-sex marriage. The objective for those on both sides was to gain the support of the public for their definition of marriage and vision of English Canada's future.

I use Jenson's universe of political discourse to expand the conception of discourse beyond just language and symbolism to ideas and (in)actions. While I believe, like Foucault and O'Barr, that a discourse is a "flow of ideas that are connected to one another" (Riggins, 1997, 3), I find it difficult to separate political language from the language of the everyday (Feldman and Landtsheer, 1998, 6). As such, language commonly used in the public sphere is relevant in a political way. In adopting this definition of political language as broad and encompassing of the everyday, I follow the trend of numerous scholars engaged in such critical analyses of political discourse (Feldman and Landtsheer, 1998, 6). This method of critical discourse analysis, however, is distinct from Foucault's definition of discourse in that it moves away from 
the "extreme relativism of Foucault" and assumes that there are elements of truth, be it belief or substantiated fact, within the discourses being critically analyzed (Riggins, 1997, 3).

Here, I apply the universe of political discourse to accommodate the broad field of analysis for this case study on the same-sex marriage debates. Analyzing the universe of political discourse permits me to examine the key political actors, both state and societal, and acknowledge the varied and multiple methods actors use to convey their message to Canadians. This analysis is not limited, however, to key actors who enter into a discursive struggle, but also recognizes the influences of supposedly neutral actors, like media outlets, who capture and relay debates to the Canadian public. This construction of arguments, reasons, and actions for and against same-sex marriage by such actors for the consumption of the public informs the universe of political discourse on same-sex marriage. Therefore, they are vitally important to explicating the nature of the battle over homosexual acceptance within the national context. Using the universe of political discourse as a tool for examining these debates, allows me to consider both "official", state-directed nationalism and "popular", societal nationalism, and, perhaps most importantly, the interactions between the two. For this case study, I relied heavily on newspaper and online news reports dating from May 2003 to March 2005. I chose these sources because they reflect the tenor of the debates that occurred on same-sex marriage in Canada at the federal level of government. It was at this time that the provincial issue of same-sex marriage reached the Appeal Courts of Ontario and began to concern Members of Parliament. With the Ontario Appellate Court decision to allow same-sex marriages in July 2003, debates continued throughout 2003, 2004, and 2005 
as key actors struggled over the ramifications of various court decisions and legislative recourse. In addition to news reports, I also incorporate selected content from the websites of actors and news sources, all of which contributed to the universe of political discourse. These documents range from official press releases from leading activist groups, online essays and articles for consumption by activist supporters. The selection of these documents, key actors, and organization was facilitated through my analysis of news sources and provides an enriched understanding and contextualization of key logic of actors missing from media reports analysed, thereby increasing my comprehension of those arguments forwarded by those for and against same-sex marriage. While the debates continued to the eventual passage of Bill C-38: the Civil Marriage Act, the timing of my study precludes any analysis beyond March 2005 .

These news reports, articles, online sources and documents were chosen specifically because they lie within the realm upon which my project is focused - the intersection of state and society. As my research is concerned with the popular discourses on same-sex marriage, my analysis of newspapers and online reports provides a selective overview of how the popular debates that occurred within and outside of the House of Commons were transmitted to Canadian society. These messages were freely disseminated to the Canadian public to either maintain confidence or allay fear of change on the issue of same-sex marriage, thereby shaping the universe of political discourse and either reifying or deconstructing what I will define as the third sexual regime. These sources should not be discounted because of their "non-official" status. Rather, I maintain that they should be unearthed and mined for their meaning, cause, and impact regarding social marginalization precisely because they blur the 
boundary between "official" and "non-official" discourses. Consequently, my selection of sources attempts to investigate and analyse both the state and society, and official and non-official nationalist discourses, in order to understand their role in maintaining or resisting gay and lesbian exclusion from the English Canadian nation.

My primary focus on the federal level of political discourse is also significant and deserves explanation. While provincial leaders do factor into my overview of the debates, it is important to recall that the period covered is that of heightened debate in the federal same-sex marriage debates which occurred after provincial court rulings in British Columbia, Ontario and Quebec. These decisions permitted same-sex marriages in these provinces and referred the matter of legislation to the federal government, where its jurisdiction over marriage renders it responsible for the definition of marriage deemed unconstitutional by the courts.

I acknowledge that the snapshot analysis of the same-sex marriage debates presented here is not exhaustive. The debates covered in the following pages do not survey the sum of the many speeches and events held on the topic of same-sex marriage. Rather, I highlight pivotal moments, individuals, and events to facilitate a different interpretation of this complex period in recent Canadian history. This case study focuses on contestation at the federal level around the traditional definition of marriage, which I argue stems directly from the sexual regime that protects this important heterosexual national institution. In Chapter Five, I analyze these debates in more detail and discuss their implications in the context of my thesis.

Finally, I approach this project from an interdisciplinary perspective, drawing from the disciplines of sociology, history, and political science. While I respect the 
boundaries of these disciplines and have attempted to use my theoretical sources in a "respectable and respectful" manner (Vickers, 1992), my interdisciplinary training provides me with a different lens through which I read, use, and interpret these disciplines, theories, and application. As a result, my project uses these texts in perhaps non-conventional ways that may challenge a strict disciplinary perspective. This fact, however, does not negate the importance or validity of this work, but, instead, may help expand the scholarly theorization of the "real" world to include the experiences (personal and collective) that cross the lines of disciplinary study.

\section{Writing Myself In}

As outlined above, my project assumes a highly critical view of civic nationalism in comparison to much of the nationalism literature canon. This view of English Canadian civic nationalism is grounded in my experience with English Canadian civic nationalism. As a Canadian-born, Black, gay, English-speaking male, I experience the exclusionary force of "our" civic nationalism more so than its inclusive tendencies. On a daily basis, my "real," lived experience lies in between the state and society, official and popular discourses, and state nationalism and societal nationalism. My experiences are not bound by neatly-created categories of state, nation, official nationalism or societal nationalism that would ease theorization and disciplinary knowledge. Rather, I am caught among all these categories which exist, influence, and impact my life, politics, and identity on a daily basis. This is where my theorization rightly focuses. Thus, it is from the "chaotic" and fluid standpoint of my daily experience of exclusion that this project emanates. 
As this "chaotic" nature of the lived experience is difficult to theorize, I limit myself in this thesis to discussions of sexuality. While I acknowledge fully the differences between gays and lesbians and their treatment within the Canadian nationstate, this preliminary examination of gay and lesbian exclusion does not explore gender difference. Historically, lesbians and gay men were treated very differently, both before the law and in popular attitude. These varying levels of regulation and exclusion are due to the different threats they are seen to represent to the nation, a differential treatment that derived in large part to women's reproductive capacity which makes women a necessary and vital part of the nation's reproductive needs. As Walby's (1997) modernization of the gender regime suggests, the dependence upon women's reproductivity has changed within the modern Canadian nation-state in comparison to Canada's original settler society. Yet, the levels of exclusion between lesbians and gays differ to this very day and among societies within Canada (e.g. the Quebecois and Aboriginal).

\section{Chapter Outline}

This thesis proceeds as follows. Chapter Two presents the conceptual framework for my study. I begin by exploring the constructed dichotomy between civic and ethnic nationalisms within nationalism literature. Here, I focus on the false nature of this dichotomy and highlight the fact that ethnic nationalist impulses remain embedded within "civic" nationalism. I then explore English Canadian civic nationalism and argue that, while inclusive elements no doubt exist, this nationalism is susceptible to exclusionary tendencies. Such exclusion is used by state, and some societal actors alike, to create the unity necessary for nationalism to flourish. Borrowing 
from Jill Vickers' race regime framework, I extend her argument to include homosexuality and argue for the existence of sexual regimes in Canada. I then propose a framework that accounts for the sexual regime's persistent exclusion of gays and lesbians from the nation.

Chapter Three explores sexual regimes in Canada. In this chapter, I maintain that Canada has had three distinct sexual regimes that continue to exert their presence on gays and lesbians within Canadian borders. The first sexual regime dates from European contact and continues to the 1920s. I identify a second sexual regime at this point in time that builds on the first and institutionalizes heterosexual relations within the nation, while at the same time regulating and purging homosexuality from the state. The final sexual regime, which I contend begins in the early 1970s and continues to the present, is distinguished by legislative deconstruction attempts. I argue that the project of deconstruction, however, is incomplete and continues daily through the equality struggles of gays and lesbians.

In next two chapters, I present my case study on the same-sex marriage debates. My main concern here is to focus on the third sexual regime. The purpose is to offer a snapshot of the contestation that is still occurring over sexuality within the Canadian nation-state and the third sexual regime's unsuccessful deconstruction project. In Chapter Four, I sample arguments used by those for and against same-sex marriage between April 2003 to March 2005. As outlined, these materials were collected from daily news sources and online resources of key actors in the struggles for and against same-sex marriage. They were then analysed for thematic debates according to the pillars of English Canadian civic nationalism discussed further in Chapter Four. In this 
discussion, I highlight the images, values, legislation, institutions and constructs invoked by key actors to make their positions within the universe of political discourse. In Chapter Five, I provide an analysis of the discussions outlined in the previous chapter. Here, I examine the tactics used by those for and against same-sex marriage in relation to English Canadian nationalism. Employing the sexual regime framework presented in Chapter Two, I use Pryke's insights on the interconnections between sexuality and nationalism to explore the expression of the same-sex marriage debate within the universe of political discourse of the third sexual regime. In carrying out this analysis, I show that the attempted deconstruction of sexual regimes is unfinished and argue that the exclusion of gays and lesbians can be expected to occur through managed integration in spite of the recent extension of same-sex marriage rights.

Finally, the Conclusion revisits the original research problem set out in this study and provides a response to the question of "whether legal guarantees can transform assumptions about belonging and identity within the Canadian nation..." (Rankin, 2000, 184). In responding to this question, I discuss the implications of this study on future gay and lesbian activism, rights and equality -seeking frameworks and the importance of taking nationalism into consideration when seeking to understand processes of inclusion and belonging in national communities. 


\section{Chapter 2: Unearthing Sexual Regimes}

Few descriptions of the past have been as idealized as traditional accounts of the origins of Western nationalism.... Nationalism in the West thus supposedly emerged as a unifying mass sentiment and participation. Specifically, it is usually portrayed as popular cohesion and loyalty to a state or inspiring efforts to build a state that conforms to such solidarity. And such solidarity has conventionally described and celebrated as tending towards inclusion within a political unit... (Marx, 2003, vii).

\section{Introduction: Defining Civic Nationalism}

According to Jenkins and Sofos, the idealized characterization of Western nationalism as a civic and inclusive phenomenon stems from a focus on the wrong phenomenon (Jenkins and Sofos, 1996). For Anthony Marx, the theoretical distinction made "between the West's civic nationalism and illiberal ethnic nationalism that emerged later or elsewhere" and acts "[a]s the central organizing principle of modern politics" is incorrect (Marx, 2003, vii-viii). The work of Canadian scholar Michael Ignatieff ${ }^{4}$ demonstrates this incorrect portrayal of civic nationalism's liberal principles. For example, he states that civic nationalism "maintains that the nation should be composed of all those-regardless of race, colour, creed, gender, language or ethnicity - who subscribe to the nation's political creed" $(1994,6)$. For Ignatieff, civic nationalism produces "a community of equals, rights-bearing citizens, united in patriotic attachment to a shared set of political practices and values" $(1994,6)$.

Ethnic nationalism, in contrast, is characterized by some as the antithesis of civic nationalism. Ignatieff differentiates ethnic from civic nationalism because of the

\footnotetext{
${ }^{4}$ I chose to use Michael Ignatieff's work to outline this incorrect portrayal of nationalism because his scholarly work has crossed over into popular discourses of nationalism. As such, his work must be critiqued in a manner which exposes his faulty logic that currently informs Canadian society at large.
} 
former's associations based on inheritance rather than choice. As a result, he writes, "[i]t is the national community that defines the individual, not the individuals who define the national community" $(1994,7)$. Thus, in comparison to civic nationalism, ethnic nationalism is thought to maintains itself through the national regime's ability to engender unity and social cohesion through a common ethnicity (Marx, 2003, 13).

In contrast to this stark dichotomization, Jenkins and Sofos (1996) argue that one must distinguish between national phenomena associated with movements struggling to achieve statehood and those employed by established nation states. Their theorization ties the political articulations of nationalism and cultural articulation of the nation to the state and political legitimacy. Consequently, they argue that it is the expression "of the 'national' to political discourses and practices, the elevation of the nation to the status of political subject that characterizes nationalism" (Jenkins and Sofos, 1996, 12). Yet, as they demonstrate through reference to ethnicity and class, "nationalisms are the product of complex social negotiations" (Jenkins and Sofos, 1996, 11). As a result, all nationalisms have the potential to take up inclusion, exclusion, authoritarianism and violence (Jenkins and Sofos, 1996, 21-22).

Regardless of these constructions of nationalism, the common attribute of all nationalisms is the notion of inclusion and social cohesion that unites all populations. Although scholars may disagree about factors which culminate in the rise of nationalism (i.e. community, national institutions, or conflict resolution), there is common ground found in the assumptions upon which they rest their theories. Smith and Hutchinson outline these beliefs below:

Nationalism was, first of all, a doctrine of freedom and sovereignty. The people must be liberated-that is, free from any external constraint; they must determine their own destiny and be masters in 
their own house; they must control their own resources; they must obey their own 'inner' voice. But that entailed fraternity. The people must be united; they must dissolve all internal divisions; they must be gathered together in a single historic territory, a homeland; and they must have legal equity and share in a single public culture (Hutchinson and Smith, 1994, 4).

Explaining nationalism's requirement of a pre-existing internal unity drives many of nationalism theorists. This "fraternity" is necessary to protect the nation from outside forces and allows for the internal and external liberation required as nationalisms develop.

This presumed unity causes the level of social inclusion through democratic, civic, or liberal principles to become civic nationalism's distinguishing feature. This chapter questions this presumption. In the next section, I interrogate the alleged inclusivity of civic nationalism. I argue that civic nationalism also exhibits exclusionary impulses and promotes qualities embodied by the nation's "ideal" citizen. To do this, I examine theoretical and empirical arguments on gender and race advanced by Canadian and international scholars regarding civic nationalism's exclusionary tendencies. I then extend my argument to account for an invisible basis for exclusion - sexuality. Finally, I conclude by suggesting the need for a theoretical framework capable of demonstrating how nationalism, through sexual regimes, excludes gays and lesbians from the nationstate, its community and nationalist discourse.

\section{Challenging the Concept of Civic Nationalism}

As illustrated, civic nationalism may foster exclusion and exhibit features assumed to be associated only with ethnic nationalism. For example, Ignatieff glosses 
over the discrimination endemic within many Western nation-states with allegedly civic nationalisms. He states,

[The civic nationalism] ideal was made easier to realize in practice because the societies were ethnically homogenous or behaved as if they were. Those who did not belong to the enfranchised political class of white, propertied males-workers, women, black slaves, aboriginal peoples - found themselves excluded from citizenship and thus from the nation. Throughout the nineteenth and early twentieth centuries, these groups fought for civic inclusion. As a result of their struggle, most Western nation-states now define their nationhood in terms of common citizenship and not by common ethnicity (Ignatieff, $1994,6)$.

In his rationalization of civic nationalism's achievement, Ignatieff contradicts his own definition of civic nationalism by acknowledging the "created" ethnic solidarity and condoned exclusion which undergirds "civic" nationalism. In doing so, he overlooks civic nationalisms dependence on "ethnic" affiliations which allow "civic" nationalism to flourish. The exclusion within civic nationalism, instead, is attributed to the democratic principle of enfranchisement rather than ethnicity. Yet, this difference remains unacknowledged by Ignatieff, but reaffirms the work of Couture et al. (1996) who expose the insidious nature of the false ethnic/civic nation embedded in some theoretical studies of nationalism.

Vickers and de Sève also find that the dichotomy between civic and ethnic nationalisms often denies "the ethnic origins and values underlying so-called civic nationalisms and their institutions, while ignoring the peaceful, democratic character of many cultural nationalisms such as those in Catalonia, Scotland, and Quebec (2000, 21)." They note how this scholarly oversight of civic nationalism's exclusionary tendencies is commonly accepted and rationalized through forgetting and omission. Likewise, Anthony Marx observes, 
The Enlightenment image of a more civic nationalism and liberal order eclipsed the memory of exclusion. Liberal individualism brought "the negation of the political," in particular the denial of conflict and its resolution. Shifts towards more inclusive political orders were in turn so legitimated, with past (or remaining) exclusions marginalized or forgotten as inconsistent. What began amid exclusion can and did become more inclusive or civic, for these are not distinct patterns, but to do so the later civic order forgot its ignoble origins and remaining flaws $(2003,31)$.

Moreover, the methods through which excluded individuals seek inclusion within the nation beyond a formal or superficial sense of belonging remain inadequately explored by theorists, who, like Ignatieff, turn a blind eye to this phenomenon.

Fortunately, there is an emerging literature which may be employed to demonstrate the exclusionary nature of civic nationalism. For instance, political scholar Erica Benner (2001) proposes a constitutive geopolitical national doctrine better able to account for the apparent incompatibility of national and liberal values. Benner's theory addresses the shortcomings of both cultural and democratic national doctrines presented within existing theory. The main element of Benner's approach is the call for conscious awareness. This awareness demands a strong, continuous nationality and/or identity, which is counted among the primary affiliations for an individual within that community through peace, upheaval, or threat (Benner, 2001, 162).

This constitutive geopolitical doctrine, however, is distinct in that it is not fixed, has no content or political affiliations. Alternatively, it is shaped by the national context-political, social, and cultural. Hence, the constitutive norm, which joins all in the territory, is the constitution of a viable political community in relation to other political communities. The doctrine and actions taken by rulers are driven by security concerns expected by all political states. This perception of threat and security, accordingly, fulfills the geopolitical aspect of the doctrine. 
While concerned with the national principle, Benner's theorization still provides a method for critically assessing civic nationalism's inclusive values and clarifies how nationalist values may be denied to individuals in spite of origins that lie in inclusion and liberalism. As she writes:

With its emphasis on strong identity as a condition for viable political community, national doctrine has tendencies to override individual or cosmopolitan aspirations when these seem to threaten the primary goals of unity and collective defence. Or to put this more pointedly, constitutive questions or boundaries and membership tend to be logically and practically prior to the questions of constitutional justice that are central to liberalism. In addition, if the prevailing constitutive values of an era privilege strong collective identities over weaker ones, as nationalism does, then individual and cosmopolitan concerns will often be given second place in practice, if not in theory (2001, 172).

Under the constitutive geopolitical national doctrine, national values and liberalism are not always compatible. When the viable political community is threatened, the demand for a strong national identity will necessarily trump one's rights or national values of equality. This fact explains the conflict that can arise within a political community when threat to the nation is perceived and how a nation's liberal values can be undermined. Benner's discussion, while set within a context of the national principle regarding the development of post-Westphalian states' constructions of nationhood, remains salient within the context of nationalisms within settler societies and their future nation-states, like Canada, as they seek the same end goal - to create and protect a national identity from other competitive territorial nation-states. ${ }^{5}$ In the case of Canada, Stasiulis and

\footnotetext{
${ }^{5}$ This conclusion is in line with the argument set forth in this thesis and the spirit in which Benner views nationalism. As she writes, "The view I describe sees nationalism as setting important constraints on political argument and action, without necessarily dominating political arenas" $(2001,173)$. The constraints in this case are placed on the inclusion of gays and lesbians within the Canadian national community and help maintain their exclusion from said community.
} 
Williams (1992) demonstrate the influence and importance of Western European thought within the context of race to protect the Canadian nation from minority threat.

Anthony Marx's concern with civic nationalism focuses on the assumption of prior homogeneity or allegiance because,

... even where there is some such common cultural sentiment within a populace, this does not necessarily bring political cohesion.... The images of common identity and unifying 'ethnicity' were instead only gradually invented constructed, and reinforced, often purposefully to bolster social cohesion precisely because it was lacking. Ethnicity or other forms of unity were not so fixed nor so firmly established as to be the necessary or only basis for state-building. Instead, diversity remained or grew within large-scale polities, with the politics incorporation of new territory, peoples, immigrants, or factions into states, threatening political unity $(2003,13)$.

The threat posed by diversity and the lack of a common identity and unifying ethnicity by default requires another basis upon which unity can be built. Marx argues, therefore, that exclusion acts as the basis for unity within Western civic nationalisms.

Marx proposes that nationalism, while externally exclusive in order to protect the freedom and security of those who belong to the nation, is also internally exclusive according to cleavages of race, ethnicity, gender, class, and religion $(2003,24)$. He continues, "Such difference has been institutionalized and reified within and by states, contrary to the assumption that states sought to unify all within" (Marx, 2003, 24). In other words, states maintain control over their legitimate national identities with an internal enemy of the state. Once identified, the internal enemy is constructed as "other" and used to solidify social cohesion amongst those belonging to the nation-state and its nationalism. Thus, nationalism's unity and maintenance depend directly on the continual inclusion and exclusion of groups within the political community or nation. 
When read together, the work of Benner and Marx create an interesting critique of civic nationalism that calls into question its inclusive and democratic nature as presented in much of the nationalism literature. Benner' core national doctrine relies on the call for a strong nationality that is dictated by the national environment and has a tendency towards illiberal practices. Hence, intolerance often, if not always, contradicts national values of equality, democracy and fairness held up within these political communities. In fact, the search for a strong unifying national identity can produce exclusion. Thus, to reconcile the tensions created by illiberal practices in a civic construction of nationalism, the nation and its enfranchised citizens invoke what $I$ characterize as a "purposeful amnesia," allowing past divisions and identities to be forgotten and erased from national history and public memory.

\section{Practically Speaking: Exploring Exclusions in Canada}

In the previous section, Ignatieff's quotation, which acknowledges the exclusion of various race and gender groups, suggests that these groups challenged Western nations to redefine the basis of nationhood to common citizenship. This process, however, is not as straightforward as Ignatieff's formulation implies. As the literature exploring social marginalization in Canada proves, struggles for inclusion by excluded groups within Canada's civic nationalism are difficult, demanding, and far from complete. This section highlights these complex struggles and their persistence within Canada.

In a special issue of the Journal of Canadian Studies entitled "Women and Nationalisms: Canadian Experiences", Jill Vickers and Micheline de Sève (2000) 
explore the experiences of women and their activism in seeking inclusion within civic nationalism in Canada. The cases they survey provide a lens through which one can interrogate the false dichotomy between "civic" and "ethnic" nationalisms. They state, "[b]y examining the roles of women in the civic and ethnic variants ...we reveal the shortcomings of this theoretical (really ideological) dichotomy" (Vickers and de Sève, $2000,13)$. Thus, by examining the exclusion of groups who desire inclusion within the Canadian community, new light is shed on the relationship of these communities to the nation and Canadian and Quebec nationalism.

Yet, in the Canadian context this task is complicated. As Vickers and de Sève document, attempts to build a single pan-Canadian civic nationalism were not successful due to the perseverance of both Aboriginals and Quebecois. This "failure" "created [a] space for the survival or revival of other collective identities which are now expressed in a democratic discourse of multiple nationalisms to which women contribute important voices" $(2000,14)$. As a result, efforts to solidify a single Canadian nationalism remain challenged by both the "ethnic" nationalisms of the Quebecois and Aboriginals and the internal ethnic diversity of its citizens. Yet, the ideal of a pre-eminent superiority of a pan-Canadian nationalism continues to resonate for the majority of Canada's citizens $(2000,15)$. In spite of this fact, Vickers and de Sève argue that there are still many others who recognize a different Canada, where diversity is a source of creativity and opportunity rather than something to fear and where multiple nationalisms coexist without the threat of conflict.

In her essay "Relational Positionalities of Nationalism, Racisms, and Feminisms" Davia Stasiulis (1999) examines the complex relationship between 
different national/ethnic feminisms and competing national projects within Canada and Quebec to which women find themselves bound and obligated to navigate. In posing the question of whether or not nationalist movements may hinder or further women's emancipation, Stasiulis makes a distinction among women who are included within the nation and those who are not. Her insights raise a second question crucial to my study, "whether a nationalist movement may oppress women who are defined as outside that nation, and who may have their own nationalist or communal self-determination aspirations" (Stasiulis, 1999, 182).

The answer to this question, she hypothesizes, lies in the exclusionary nature of nationalism or its capability to "recogniz[e] and validat[e] other nationalisms and ethnic minority claims, together with the demands of women's liberation within these competing national/ethnic projects" $(1999,182)$. Here, the tension and threat created for a civic nationalism is clear. As Stasiulis demonstrates in her study of pan-Canadian, Quebecois, and Aboriginal feminisms, there are varying degrees to which each group can move beyond their exclusion within and among competing nationalisms. Inclusion, therefore, depends directly upon the power and position of the group at the time of contestation in relation to those other groups struggling for inclusion. Those easily aligned with the dominant "fictive ethnicity" and values of society will reap greater rewards and benefits for their efforts (Stasiulis, 1999, 182-183).

English Canadian civic nationalism, based upon liberal, democratic principles that unify all those within its territory, is called into question by the above studies.

\footnotetext{
${ }^{6}$ Integral to the nation, fictive ethnicity, according to Etienne Balibar, is comprised of two elements: 1) a linguistic ethnicity which is open and can be easily adopted by individuals; and 2) an ethnicity which is predominantly racial and exclusionary. The use of this concept by Stasiulis reveals the potentially closed nature of a nationalist project that holds women at differing levels of exclusion within a territory (Stasiulis, 1999, 182-183).
} 
Moreover, Stasiulis' research reveals that even within a pan-Canadian nationalism that counts diversity among its values, there is still a degree of exclusion within its construction. It appears that, in spite of its civic nature, English Canadian nationalism continues to be linked to a common ethnicity. Although fictive in nature, the ethnicity of the ideal Canadian seems to correspond with physical and social characteristics (specifically white, male and English-speaking) that do not match or acknowledge the diverse, gendered society Canada officially celebrates.

The ethnic foundations of English Canadian civic nationalism become more evident when examining the exclusion of race minorities within Canada. As we have seen above, women have struggled for inclusion but their struggles are often determined by their position within the nation. In the case of race, Canada's history as a settler society furnishes a fertile backdrop for the development of exclusions based on race in our political system. Stasiulis and Jhappan (1995) and Vickers $(2000 ; 2002)$ in their work on race in the Canadian settler society demonstrate the extent to which race is "deeply embedded in our political systems despite efforts in recent decades to achieve internal decolonization and to remove 'race' bias from state institutions" (Vickers, 2002, 16). To argue this point, Vickers employs the concept of race regimes. She describes a race regime as a political system which consists of structures, such as legislatures and public institutions; ideas, like racialist ideologies; and relationships, such as those between citizens and the state or classes. For Vickers, race regimes are identifiable according to oppression experienced by race minorities and are built upon one another. As such, race regimes provide a nuanced understanding of how race is constructed by the state and reproduced through nationalism and national institutions. 
As she documents, the internal colonization of Aboriginal peoples derived from European race doctrines was based on pseudo-scientific theories of racial hierarchies. These race doctrines sanctioned European racial superiority and condoned the colonization of Aboriginal peoples and the theft of their lands. This initial race regime, based upon the colonization of Aboriginal peoples, expanded in the post-Confederation era. The second race regime was built upon explicit exclusions grounded in visible race distinctions. In this case, "undesirable" races were denied entry and citizenship within the Canadian nation-state. Stasiulis and Williams prove that there was an ideological project among political elites to adapt these European-inspired race doctrines to the Canadian environment $(1992,2)$. As a result, British, French and European immigrants excluded Chinese and other visible race minorities because of their race based upon a new, adapted "Canadian" race doctrine.

As Vickers surveys, the end result was a racial hierarchy which tolerated race minority individuals already within the state and excluded those who sought to make Canada their new home. ${ }^{7}$ Governmental policies relegated race minorities to the status of denizen within the Canadian national community on the basis of their race. Here, experiences of indentured labourers and Black Loyalists illustrate the marginalization within the early Canadian nation building process. As a result, the deliberate exclusion and regulation of race minorities by the Canadian nation-state protected and perpetuated Canada's "whites-only nationalism". 8 These race regimes, while operating through

\footnotetext{
${ }^{7}$ Stasiulis and Williams do an excellent job of showing the wide array of positions surrounding the citizenship debates in Hansard between 1860-1914 (Stasiulis and Williams, 1992). In spite of these ideological differences, exclusion was still enforced at borders even though such exclusionary standards were not legislated.

8 "Whites-only nationalism" is a term used by Vickers to describe Canadian, Australian and American nationalisms. These nationalisms are based on racial solidarity or whiteness. State policies sought to
} 
different modes of oppression, were not static. At the core of race minorities' exclusion in the Canadian nation-state was the notion of the 'suitable' Canadian, who was considered to be white and Northern European (Strong-Boag, Grace et al., 1998, 8). Over time, however, the integration of local "safe" groups, like excluded ethnic minorities and certain race minorities (i.e. Japanese-Canadians) was permitted. The determining feature of minority inclusion became the maintenance of Canada's whiteonly nationalism.

As Vickers traces, increased immigration from non-European countries made diversity a major concern of government. To manage this perceived problem, the Canadian government adopted a multiculturalism policy. Yet again, the core of these changes focuses on the concept of race which is used as an identifying feature to separate those who belong from those who do not. This semantic shift, however, disguised a new discourse that replaced race with ethnicity. Evidence lies in the evolution of government defined terminology describing Canadian diversity (Day, 1999, 184-199). However, these definitional changes were necessary to create the stable ethno-cultural identities essential to multiculturalism (Day, 1999, 205). These factors highlight the failure of the attempted deconstruction of Canada's race regimes.

According to Vickers, race regimes currently are undergoing deconstruction $(2000,97)$. This process of deconstruction generally has occurred through legislative change in the form of amended immigration policies, and equality and affirmative action legislation. Yet, efforts to right past wrongs through legislative change only gave rise to a new race regime: democratic racism. As Vickers quite convincingly argues,

actively exclude and deny citizenship to non-whites and reduced non-whites in these countries to the status of denizen (Vickers, 2000, 81). 
democratic racism replaces the previous race regimes of internal colonialism and exclusion (2000, 97-99). Democratic racism, like the former race regimes, continued the oppression of certain race minorities, while privileging the majority race. It differs from the old race regime in that it brings together values of democratic equality and racism (Vickers, 2000, 99). ${ }^{9}$ This new regime fits the previous system of exclusion by refusing to unsettle White Canadian civic inclusion and the exclusion of the "other-ed" race minority.

Using Vickers' race regime framework, Canada's adherence to doctrines that oppress and exclude race minorities from equal participation and benefit within Canadian society is evident. This race-based exclusion persists in spite of democratic values, institutions, and symbols implemented by government and embraced by Canadian citizens. While this framework illustrates that race regimes existed and continue to impact race minorities in Canada, there is one characteristic that often is omitted in this discussion of exclusion - sexuality. In the next section, I extend this argument to include sexual orientation as a basis for exclusion from English Canadian civic nationalism and civic nationalism more broadly. I contend that, as with democratic racism, the current sexual regime embraced gays and lesbians more fully from a legal standpoint, while still exhibiting vestiges of what one might term "democratic homophobia."

\footnotetext{
${ }^{9}$ An excellent example of democratic racism is Canada's multiculturalism policy. This policy, while attempting to create an opening in Canadian nationalism for race minorities, falls prey to two core issues which belie its good intentions. First, it does not address Aboriginals and the internal colonialism that continues to oppress their communities. Secondly, multiculturalism does nothing to re-imagine or recreate the Canadian community. Instead, multiculturalism serves to manage diversity and keeps white English Canadian culture at the heart of the Canadian identity and does nothing to unsettle this notion (Lee and Cardinal, 1998).
} 


\section{Homosexuality as a Basis for Exclusion}

To this point, I questioned the assumptions of Western civic nationalisms as liberal, inclusive, and accepting of diversity and difference. Because of its need to protect the national identity and social cohesion, nationalism often furthers its own interests for unity over the desires of the individuals within its territory. As a result, civic nationalisms have the capacity to be illiberal and exclusive in order to protect the strong identity required for the development and maintenance of nationalism. Marx explains the means through which this breakdown in civic nationalism may occur exclusion. According to Marx, providing a strong base upon which the nation may maintain its security and autonomy justifies the exclusion of a few to unify the remaining individuals within the state.

As discussed, feminist research has long revealed the exclusionary and sexist roots of English Canadian civic nationalism. Moreover, the English Canadian version of civic nationalism remains contested by competing ethnic nationalisms and racial diversity. This Canadian reality results in varied levels of inclusion for women, ethnic, and race minorities. Challenges for inclusion are far from over, however, and continue to occur with gains and setbacks seen by both groups closest to inclusion and those still held far outside of the nation. While certain rights, legislation, and guarantees extend to race minorities, exclusion from full citizenship continues as the democratic majority refuses to release their hold on power and imaginings of the nation that rest on racial and ethnic ideals of the past (Vickers, 2000).

Yet, in the work of both Marx and Benner, the only cleavages identified upon which exclusion may be based are race, gender, ethnicity, class, and religion. To 
address the omission of sexualities from the above list, this section argues that sexuality, specifically homosexuality, constitutes a very real and potent ground for exclusion. I contend that homosexuality is invoked to unify a strong national identity for the purposes of protecting the nation and this invocation continues to exclude gays and lesbians from belonging to the nation.

Of use at this point is the work of Sam Pryke (1998) on nationalism and sexuality. In his study, he identifies three major interconnections between the two phenomena. The first interconnection is national sexual stereotypes which are often linked with race and ethnicity. These stereotypes are based on the "alleged excess or absence of various sexual attributes of a nationality: lust, promiscuity, virility, passion, and perversion among others" (Pryke, 1998, 534). Sexual stereotypes are not permanent. Instead, they shif and emerge at important junctures within a nation's history. The second interconnection is sexuality in national conflict. While often envisaged as rape during warfare, Pryke takes a broader interpretation of sexuality in national conflict. Here, sexuality is seen in the context of security and threat. As such, sexual threats prescribe a need to defend national cultures and identities from immoral and unconventional sexual practices. Within this context, stereotypes of the "sexual other" gain further meaning and importance. The final theme is sexuality in nationbuilding. This interconnection involves the control and regulation of sexuality for the well-being of the nation. Much less evident than sexuality in national conflict, sexuality in nation-building supports acceptable sexual behaviour and practices for the health of the individual and the nation, including the regulation of fertility through law and legislation. 
These three interconnections between nationalism and sexuality reveal their dependence upon one another. The regulation of a sexually "healthy" nation is deemed necessary for the creation and maintenance of a strong national identity among individuals which allows them to reproduce future generations of citizens. The deceptive omission of sexuality as an exclusionary cleavage upon which unity is built can be easily understood in the way that sexuality seems to easily align itself with gender, race, and ethnicity (Pryke, 1998, 533). For example, Pryke considers these intersections within the context of the black male during America's history of slavery and segregation. Here, sexual stereotypes around the virility and violent sexuality of black males historically resulted in the regulation of mixed race marriages and severe prosecution of these men in cases of rape against white women (Pryke, 1998, 533).

In the context of Pryke's analysis, therefore, homosexuality can pose a significant threat to the nation. The threat of homosexuality increases with an openly out and active homosexual identity that potentially conflicts with the strong national identity Benner identifies as required for nationalism to flourish. Furthermore, a gendered conception of the nation is required to unlock fears of potential threat from this "immoral" homosexual identity (Rankin, 2000, 179). With these conditions, homosexuality may be a very potent point of exclusion. For as Becki Ross observes, “[n]ationalist projects have always involved processes whereby populations are divided into racialized, sexualized, and gendered categories of belonging and otherness" (1998, 189). Sexual stereotypes of homosexuals that commonly construct gays and lesbians as promiscuous, immoral, and less than human (albeit to different degrees for gays versus 
lesbians) because of their deviant sexuality are clearly recognizable, resulting in their categorization of "other" within the nation.

The homosexual threat to the nation can be observed in the protection of heterosexuality upon which the nation is based. As Rankin states, "When we look at nationalisms and sexual identity...we see that homophobia functions as an integral element of most nationalisms" (Rankin, 2000, 178). Thus, the allegedly immoral sexual practices of homosexuals pose a threat not only to the morality of the nation, but also to the base upon which the nation and its nationalism are based - heterosexuality. This threat also has broader implications that connect with sexuality in nation-building.

As mentioned above, the regulation of sexuality has been used by nations to ensure a strong nation-state. Part of the required elements to perpetuate the nation is the nuclear or traditional family.

The family trope is important for nationalism in at least two ways. First, it offers a 'natural' figure for sanctioning national hierarchy within a putative organic unit of interests. Second it offers a 'natural' trope for figuring national time (McClintock as cited in Rankin, 2000, 179).

Hence, the family can be seen as a pillar upon which the nation relies. The exposure of homosexuals, their sexual practices, and their relationships shakes the very foundation of this heterosexist construct.

Thus, the nation-building process comes under attack from various levels with the acknowledgement and acceptance of homosexuality. First, it potentially discredits the sexual stereotypes about gays and lesbians and draws their illegitimate sexuality into the nation. Second, it causes internal conflict with and threatens the perceived heterosexuality upon which the nation and its state are based, blurring gender lines and tropes that have been imagined and cultivated within a society to reproduce the nation. 
Finally, it shakes the foundational unit of the nation assumed to be required for nationbuilding - the nuclear or traditional family. These powerful stereotypes and constructs of nationalism have the power to unify individuals beyond the differences of gender, race, ethnicity, class, and religion. It then becomes easy to see how homosexuality can be considered another ground for exclusion from nationalism that may result in the unity of other groups from various cleavages within the nation.

\section{Building a Theoretical Framework: Sexual Regimes}

To this point, I have argued that civic nationalisms are illiberal and can exclude certain groups within a given society. As Benner notes, the need for a strong national identity to maintain the unity required for nationalism to flourish may result in the exclusion of certain groups to protect the national community. In the name of this protection, the individual (or minority) will necessarily have their rights suspended or revoked to assure the supremacy of the nation and its political community. As Marx shows in relation to civic nationalisms, the basis for unity within the nation-state also is derived through a form of internal exclusion in which an "other" is identified and used to unify those suitable citizens within the nation. In joining the works of Benner and Marx, I contend that exclusion within English Canadian civic nationalism always maintained internal "others" in order to solidify a strong Canadian identity. As the research on women and race minorities illustrates, the ideal Canadian is both gendered and raced. Moreover, the exclusion of both these groups continues to this very day despite changes in our Canadian legislation that support racial and gender diversity. 
The persistence of these continued struggles for inclusion signify, for me, a deeper structural issue at work that is in need of exploration. Vickers' race regime framework lends the insight needed to help illuminate the racial exclusion within the political regime. As outlined above, her framework identifies three consecutive regimes within which the exclusion of racial minorities occurred. The colonial regime functioned to ensure the internal colonization of Aboriginal peoples. The second, layered on the first, physically excluded race minorities from entering the country and discriminated against those already within its borders. The final regime deconstructs the previous two through legislation and court decisions. This has not, in spite of government rhetoric celebrating diversity, been successful as evidenced by the continued discrimination and exclusion of race minorities in Canada.

I argue that sexual minorities are subject to such exclusionary tendencies as well. While conceptions of the ideal citizen are raced and gendered, they are also sexualized and privilege heterosexuality. Taking this fact into account, I contend that homosexuality can be and is considered a threat to the nation. With homosexuality defined as grounds for exclusion from the nation that may be used to unite included heterosexuals or closeted sexual minorities, I suggest that, similar to the race regimes which oppress and exclude race minorities, sexual regimes work to systematically exclude and discriminate against gays and lesbians within civic nationalisms with the purpose of maintaining a heterosexual national identity.

While Vickers identifies race regimes as a political system, I deviate somewhat from her definition. My usage of "sexual regimes" refers instead to socio-political systems that encompass structures, ideas and relationships both within and outside of 
the state. This distinction is made to recognize the fluidity which can be witnessed in the creation, maintenance, and contradictions of societal practices and "norms" of sexuality both within the state and the broader national community. I thus view both the state and society as constitutive, mutually reinforcing elements of sexual regimes.

Finally, as noted by Pryke, gender and race is fused with notions of sexuality. With Walby (1997), I acknowledge the profound role of gender regimes, but in this preliminary study, I concentrate my analysis more specifically on issues of sexuality. Certainly, the nationalist discourses I explore later in the thesis operate differently with respect to lesbians than to gays and will be influenced also according to other identity markers such as race. Thus, my conclusions in this thesis should be seen as a starting point that can lead to future work examining more closely the impact of exclusionary nationalist discourses or "democratic homophobia" on gays, lesbians and other sexual identity groups that are also defined by their race, class and ability identities.

Sexual regimes, like race regimes, are inspired by the desire to protect the nation and its state. They manifest themselves through the regulation of citizens' sexuality and construct positive and negative ways of being sexual within the nation-state. These constructions of sexuality reproduce the nation, in keeping with the gendered, raced, and sexualized "norms" of society. It can then be expected that sexual regimes produce, reinforce, and protect supposedly positive images of the nation's sexual identity. Above, I outlined how a strong gay and lesbian identity comes into conflict with the heterosexist identity of the nation, resulting in the exclusion of gays and lesbians from inclusion within the nation. This exclusion, I argue, manifests itself through sexual 
regimes, which can be traced more fully by employing Pryke's three interconnections between nationalism and sexuality.

Pryke's analysis reveals that sexual regimes produce, reproduce and maintain "positive" national sexual stereotypes. These sanctioned images of the nation's sexuality are designed to create distinctions between "good" and "bad" sexualities, thereby minimizing levels of lust, promiscuity, virility, passion, and perversion that fuel negative sexual stereotypes of a nation. At the same time, the nation promotes images of a nation with insignificant levels of sexual deviance and flourishing levels of healthy and respectable sexual practices among the nation's citizens. Second, in the context of sexuality in national conflict, sexual regimes protect and encourage the state-sanctioned heterosexuality and heterosexual practices through the structures of the political regime. As a result, positive legislation, sexual education, and public health initiatives are all implicated in this process of protection. On the other hand, the protection of heterosexuality also requires the deterrence of deviant sexualities and sexual practices. The regulation of sexuality, enforced through the sexual regime, encompasses legislative, judicial, and protective acts of the political regime. Finally, sexual regimes encourage and promote nation-building through institutions and incentives that make it attractive for the nation's citizens to procreate. Here, marriage and the traditional family are constructs through which the nation reproduces itself. To make these options more attractive to citizens, incentives such as subsidies, and tax breaks are legislated and societal privilege offered. The punitive reach of the sexual regime, however, is always in force to protect these institutions and punish those who do not adhere to the "norm." 
Hence, sexual regimes in their protection of heterosexuality delegitimize any other sexual orientation or practice that goes against the nation's sanctioned sexuality. This, I contend, extends to homosexuality expressed openly within the nation as a valid and legitimate option for the nation's citizens. The acceptance and legitimization of homosexuality within the nation poses a serious, ongoing concern for the nation-state. This concern can cause sexual regimes to shift or use multiple lines of protection to ensure its continuity over time. This line of thinking is in keeping with Sylvia Walby's rounds of restructuring. She states:

Rather than this notion of one critical period of 'nation-formation', it is more appropriate to talk of 'rounds of restructuring' of the nationstate.... It is useful in carrying the notion of change built upon foundations which remain, and that layer upon layer of change can take place, each of which leaves its sediment which significantly affects future practices (190).

Through such rounds of restructuring, the sexual regime maintains its exclusionary power over time. Social marginalization of gays and lesbians occurs through varying methods and to varying degrees to safeguard the unity and survival of the nation building project and its compulsory heterosexuality.

\section{Conclusion}

In this chapter, I argued that Canada's civic nationalism is not as inclusive or united as it may appear. I began by questioning the assumptions of scholars who study civic nationalism. I then explored the concept of civic nationalism, defining civic nationalism as a modern phenomenon that has tendencies towards exclusion. Using literature from the Canadian context, I demonstrated how the Canadian reality matches the exclusionary definition of civic nationalism, holding groups outside of its belonging according to ease of integration. To make this argument relevant for this study, I 
expanded the foundations upon which civic nationalism may exclude to include homosexuality. Finally, I borrowed from Vickers' race regime framework to show how the exclusion of homosexuality manifests itself through sexual regimes that defend the nation's compulsory heterosexuality.

In Chapter Three, I illustrate how sexual regimes function in Canadian society. I categorize three discrete sexual regimes throughout Canadian history, showing the historic role of English Canadian nationalism in excluding gays and lesbians from the nation. Finally, I utilize Pryke's analysis to further explore the operation of sexual regimes within the Canada. 


\section{Chapter 3: An Overview of Canada's Sexual Regimes}

\section{Introduction}

In the previous chapter, I proposed a framework for understanding sexual regimes which contribute to the exclusion of gays and lesbians from belonging within the nation as legitimate, proud and "out" citizens. I argue that sexual regimes support the nation's compulsory heterosexuality and sanction acceptable social institutions and sexual relations among its citizens to encourage procreation, nation-building, and the preservation of a strong national identity. I contend that English Canadian civic nationalism's sexual regimes maintain homosexual exclusion in spite of valiant efforts for inclusion by gay and lesbian communities. It is within this context of systemic sexual marginalization that gay and lesbian Canadians struggle to resist legal and legislative inequality within the national community.

The purpose of this chapter is to provide an overview of Canada's sexual regimes. I posit that three sexual regimes regulated the sexuality of those individuals who live within its borders over the course of the Canada's history. Following Cannon $(1998,2)$, I argue that the first efforts to exercise control over the sexuality of indigenous populations coincided with European Missionary contact in the late $1600 \mathrm{~s}$, but I date the first sexual regime as fully identifiable after the War of 1812 . In the second sexual regime which lasted from the 1920 s to 1960 s, sexuality and gender roles were regulated increasingly by the Canadian state. During the early $20^{\text {th }}$ century, the prevailing climate of moral regulation contributed to the publication of many psychological studies focused on the "pathology" of the homosexual. Later, the introduction of the post-World War II Canadian welfare state and emergence of anti- 
homosexual campaigns in the 1950 s and 1960 s reinforced the nation's compulsory heterosexuality and discouraged alternative sexualities. Finally, the current sexual regime, which began in the early 1970 s, is undergoing deconstruction. Actors within the English Canadian nation-state are in the midst of legislatively dismantling the Canadian sexual regime. I argue, however, that the final result of this project remains unclear.

I offer this periodization of Canada's three sexual regimes to sketch the existence and operationalization of sexual regimes from first contact to the present day. My historical survey of sexual regimes does not attempt to address the agents/methods of change between sexual regimes. Instead, my purpose in this chapter is to explore the manifestation of Canada's three sexual regimes over time. Moreover, I seek to clarify the events and forces that construct each sexual regime affecting gays and lesbians. It is for this reason that following each description I illustrate the operation of the three sexual regimes using Pryke's analysis. With my focus on sexuality, I again do not address the gender regime in detail, but recognize the variation in exclusion created by the gender regime that differentiates the experiences of lesbians and men within each sexual regime. Finally, I wish to illustrate the usefulness of sexual regimes for understanding the intersections between the state and society from which the experiences of exclusion around issues of homosexuality arise. The promise of sexual regimes to analyse and interrogate this middle ground of experiential exclusion will be explored in more depth, however, within my case study on the same-sex marriage debates. 


\section{The First Sexual Regime: The Colonial Implementation of Regulation}

In Canada, efforts to regulate the sexuality of indigenous populations in North America emerged long before the founding of the Canadian nation-state. In his exploration of this early regulation, historian Martin Cannon writes,

Even prior to Confederation and the first statute entitled the Indian Act in 1876, the colonial enterprise in Canada had virtually enforced a system of Eurocentric policies, beliefs, and value systems upon First Nations. The earliest missionaries, for example, were determined to "civilize" the Indian populations by attempting to indoctrinate a Christian ethos and patriarchal family structure. It was within the context of such a conversions mission that same-sex erotic and sexual diversity was negatively evaluated and often condemned. This mission was a project fuelled by heterosexism $(1998,2-3)$.

The foundation of such regulation is apparent in the racist and heterosexist beliefs of religious missionaries sent to "civilize" indigenous peoples. Sexual regulation took the form of condoned heterosexuality and, acting in tandem with the ideologies of racial superiority, began to cement the oppression and destruction of Aboriginal customs and sexual relations.

The differences in sexual practices and behaviour between Europeans and Aboriginals have been well documented (Cannon, 1998, 7). A sexual freedom among women, social and biological diversity in third and fourth genders, and various erotic relations, including European-defined sodomy, are some examples of the open sexuality expressed within North American indigenous groups (Lang, 1997, 100-101). Following contact, these practices were immediately characterized as inferior, and measures were pursued to encourage Eurocentric heterosexual models. Cannon cites the journals of Missionary Jean Bernard Bossu, who resided in North America from 1751 to 1762 , to provide insight into Christian perceptions of North American Aboriginal sexuality: 
The people of this nation are generally of a brutal and coarse nature. You can talk to them as much as you want about the mysteries of our religion; they always reply that is beyond their comprehension. They are morally quite perverted, and most of them are addicted to sodomy. These corrupt men, who have long hair and wear short skirts like women, are held in great contempt (as quoted in Cannon, 1998, 3).

The words of Bossu illustrate a desire to eliminate the sexual diversity present in Aboriginal cultures. These initial perceptions of such missionaries set the tone for Aboriginal-missionary relations. Indeed, such prejudices against diverse Aboriginal sexualities laid the foundations upon which the first sexual regime was built and heterosexuality entrenched in "civilized" North America. Despite Cannon's evidence, it is true that during the fur trade, European efforts to exercise control over Aboriginal sexuality were minimal, given the absence of institutionalized state structures and the vested interest both the British and the French had in solidifying trade and military relationships with Aboriginal nations. Yet, during this same period, initiatives such as les filles $d u$ roi $^{10}$ sent to settlements in New France suggested that colonial authorities were interested in ensuring that proper family units were populating the colonies.

A century and a half later, however, by the end of the War of 1812, Indian allies were no longer needed as the French had already been defeated almost fifty years earlier, and the boundaries with the United State grew more stable. I would argue that it is at this point that the first fledgling sexual regime emerges. Certainly in this colonial period, state control over family relationships was tenuous as, arguably, control over the settler populations did not focus primarily on intimate sexual practices, but rather

\footnotetext{
${ }^{10}$ Between 1663 and 1673 , over 700 filles du roi were sent to North America by Louis XIV. Concerned with the growth of New France, Louis XIV subsidized the importation of these women to strengthen the development of the colony and help them earn their independence from France. Each woman, while not an actual daughter of the King, had all their travel expenses paid. In many cases, they were also provided a dowry and a chest with needles, thread and other supplies to help them begin their households (Gagner, $2001)$. Once in New France, these women were expected to marry and procreate.
} 
whether settler populations would continue to grow and flourish. It is not until state control grows more entrenched in the post-Confederation period that the sexual regime takes hold more permanently.

Kinsman argues, however, that alternate forms of sexuality, gender, and erotic encounters were deemed unacceptable and immoral very early on within North American settler societies. As he notes, "[t]he interdependent [heterosexual] household became the main form of social life" in North American colonies for both survival and population renewal and maintenance $(1996,98)$. Working and military men, however, were presented with increased opportunities for same-sex relations. During the mid to late1800s, it was not uncommon for men in logging towns, remote work stations, or in military settings to engage in many forms of sexual contact including buggery and sodomy which were considered criminal acts under Colonial law (Kinsman, 1996, 110). As a result, relations between men in these settings were highly regulated by the community to avoid these crimes. In New France and Upper Canada, the consequences for those caught could result in death. This maximum penalty, however, rarely was applied. Instead, the criminal was often imprisoned or banished from the community (Kinsman, 1996, 99).

The above point raises a number of interesting observations surrounding this first sexual regime. First, sexual regulation focused mainly on men's sexual activities. Relationships between 'independent women' were not subject to the same level of criminalization as those between men. ${ }^{11}$ Second, regulation was a community effort.

\footnotetext{
$"$ Ross observes that independent women were perceived much differently than men who engaged in sodomy or buggery. Instead of being characterized as 'criminal' or 'deviant,' 'independent women' who eschewed their patriotic obligation to motherhood and wifedom were widely perceived as disorderly, amoral, and a threat to the foundations of civil society and "laws of nature"" $(1998,191)$.
} 
The regulation of the sexual regime was sanctioned both by colonial governments and the community. This observation demonstrates the perceived importance of sexuality to the survival of the colonies and their communities. Finally, the punishments for sodomy and buggery reveal the extent to which such behaviour was pathologized within the community. That men who engaged in such activities were often removed or banished from the community illustrates the perceived threat to the survival of the community and colony.

Like race regimes, sexual regulation strengthened following Confederation. As a result, "the social relations in which English legal history and practice had developed were thereby integrated into the foundations of the Canadian state" (Kinsman, 1996, 110). In addition to legal reinforcement, ideas about both appropriate sexual behaviour and what it meant to behave as an appropriate citizen of the nation were spread through the educational system, a key tool of civic nationalism that not only reinforced state power and compulsory heterosexuality but also inculcated populations, both Aboriginal and non-Aboriginal with norms and values about the nation and nationalism. ${ }^{12}$

Pryke's analysis of the interconnections between nationalism and sexuality aids in unravelling the complexities of this first sexual regime. The sexual stereotypes are unmistakable witnessed in the writings of Jean Bernard Bossu. Descriptions of Aboriginals as "morally perverse" and "addicted to sodomy" contributed to the sexual stereotypes imposed on these groups in order to maintain the supremacy of European

\footnotetext{
${ }^{12}$ The education system played a strong role in the maintenance of gender roles and heterosexuality. As Kinsman notes of the mid-1800 to early twentieth century, "the school system played an ever more important role as it extended to more and more young people in making "citizens" and a Canadian public" (Kinsman, 1996, 107). As a key tool of nationalism, residential schools, run by Anglican, Roman Catholic, and United Church clergy, acted as a means to "civilize" aboriginal children and teach them "proper" European, Christian morals (Warner, 2002, 31-32). For more information on residential schools in Canada, consult Milloy, 1999.
} 
ideas about heterosexuality. These sexual stereotypes of North American indigenous people, combined with their perceived racial inferiority, resulted in assessments of their sexual practices as inferior and deviant. In turn, sexual stereotypes justified missionaries' perceptions that the alternative sexual practices among Aboriginals should be eliminated and controlled.

The perceived necessity to control and eradicate the diverse sexuality of Aboriginal peoples and the desire to impose similar restraints on other citizens demonstrates the perceived threat of alternative sexualities to the founding of the Canadian nation-state. As a result, Aboriginals became the targets of conversion, "civilization", and regulation. Within early colonies, state regulation increasingly replaced community and self-regulation. Laws were adopted and, in the case of Indian Act of 1876, (Cannon, 1998, 9-13), created to maintain the domination of heterosexuality within the colonies and the emerging Canadian nation.

The regulatory efforts within setter societies also successfully supported the third interconnection between sexuality and nation-building identified by Pryke. As the Canadian nation developed in the post-Confederation period, the state's preoccupation with the marriage and procreation of its citizens increased, producing a climate in which the endorsement and enforcement of heterosexuality was regarded as integral to the survival and future of Canadian society.

\section{The Second Sexual Regime: Enforcing National Security}

As Canada matured, negative attitudes towards vice and immoral sexual practices continued to have a significant impact on the way sexuality could be 
expressed within English Canadian society. To maintain order within the nation, the regulation of poverty, crime and vice was commonplace by moral reformers through the early decades after the turn of the century (Valverde, 1991, 130-131). Among the vices deemed in need of regulation was homosexuality. During early $20^{\text {th }}$ century, homosexuality received much attention from psychologists. Homosexuals were the subject of many unflattering studies that reduced their sexual attractions to sexual perversions. In Richard von Krafft Ebing's Psychopathia Sexualis, homosexuals were defined as a individuals with a "physiologically based psychiatric pathology attributable to congenital weakness of the nervous system" (Warner, 2002, 22-23). The medical and social stigma attached to homosexuality required gays and lesbians to remain inconspicuous and unnamed.

Increasingly marginalized from mainstream society, gays and lesbians developed submerged networks in cities where they could gather, express their sexuality, and find companionship after the Second World War (Warner, 2002, 49-51). Yet, because cities continued to be highly community regulated (Warner, 2002, 50), gay and lesbian sexual and social systems existed underground and relied heavily upon secrecy and custom. Strengthened networks in urban areas soon spread into rural English Canada throughout the post-WWII period. This set of connections fostered and produced safe spaces for same-sex experiences (Warner, 2002, 49). Public, private and semi-private spaces, like clubs, parks, public washrooms, and homes, provided areas through which lesbians and gays could meet others who shared their attractions and explore their same-sex desires (Warner, 2002, 50). Public lesbian and gay communities emerged from these networks and built a sense of kinship, commonality, and belonging 
for gays and lesbians. Public communities, however, made gays and lesbians prone to increased regulation.

The entrenchment of the second sexual regime accelerated after WWII. This important period of nation-building saw the introduction of Canadian citizenship legislation and the attempted adoption of national symbols such as the Canadian flag designed to create a Canadian identity separate from that of the nation's British origins (Martin Sr., 1993). Additionally, the national federal welfare system's development strengthened the institutionalization of heterosexuality throughout English Canada. Financial support, such as family allowances, benefited those citizens that produced Canadian children (Martin Sr., 1993, 67). While supporting the nation-building project of the day, these monetary incentives for citizens within heterosexual relationships reinforced traditional gender roles, reinforced interactions between the sexes, and entrenched heterosexuality further within Canadian legislation. As Smith observes,

The state enacted legislation "constitutive of a family in which dependence of women and children ... became legally enforceable and ... progressively incorporated into the administrative policies of welfare agencies, education, health care, etc. ... The man as breadwinner and the woman as dependent become the legally enforceable and administratively constituted relation" (as quoted in Kinsman, 1996, 135).

Clearly, heterosexuality was integral to the growth of the Canadian nation-state. Furthermore, the Canadian nation-building project of financial support to the family made heterosexuality the only sanctioned vehicle for inclusion within the national community.

The 1950s marked a new period of sexual regulation focused on the homosexual. Ushered in by the McCarthy era's "Red Scare," numerous groups were identified as enemies of the Canadian nation-state, including women, Quebec 
sovereignists, youth, Black, Native and political activists, immigrants, and unionists to name a few (Kinsman, Buse et al., 2000, 3). Gays and lesbians, identified as enemies of the state, became the subject of intense scrutiny by officers of the Royal Canadian Mounted Police (RCMP) and local police departments. Security officials believed homosexuals to be untrustworthy because of their allegedly deviant sexuality. As a result, gays and lesbians were labelled threats to the nation. This classification prompted the allocation of increased manpower and finances to oversee the removal of homosexuals from the Canadian civil service and armed forces. To justify this expenditure, state officials invented "character weaknesses" to ensure gays and lesbians fulfilled the "enemy" role.

"Character weakness," linked solely to gay and lesbian individuals, became the main rationalization security officials used to decry homosexuality within the public service (Kinsman, 1995, 144, 2000, 144). These "weaknesses" supposedly increased gay and lesbian vulnerability to blackmail, coercion, and other illicit behaviours, such as "drunkenness, adultery, and "promiscuity" (Kinsman, 1995, 145). As a result, the term assumed a gradually more homosexual connotation and became a code word for homosexuality within Canadian security practices (Kinsman, 2000, 144). ${ }^{13}$

The association of character weaknesses with homosexuals justified increased surveillance of homosexuality within the civil service. Security panel documents confirm this preoccupation. An internal memo by D.F. Wall, secretary of the Security

\footnotetext{
${ }^{13}$ For a full discussion of the evolution of "character weaknesses" and their relationship to gays and lesbians as created by members of the Security Panel, please see Gary Kinsman (1995, 2000). It is important to note, however, that these events had a more significant impact on gays rather than lesbians, given that gender discriminatory practices as the time dictated that fewer women than men held senior posts within the Canadian civil service, and therefore, were not seen to constitute as serious a security threat.
} 
Panel, states, "It is the Prime Minister's wish that the matter be examined to determine whether it might be possible to treat cases of character weaknesses differently than those involving ideological beliefs, without out of course weakening present security safeguards" (Kinsman, 1995, 145). This quotation reveals the distinction made between political disloyalty and that of character weaknesses (or homosexuality) within the security discourse which, in turn, legitimated the expansion of homosexual surveillance and regulation by the state and RCMP.

In conjunction with the anti-homosexual campaigns, the second sexual regime also attempted to regulate gender roles in other ways. One example within the public service was the establishment of the Miss Civil Service beauty pageant and the "Ottawa Man." During the Cold War period, gender/sexual anxiety created the need to establish stable models of femininity and masculinity (Gentile, 1996, 33-34). Gentile writes,

Yet, even at the apex of the seemingly "natural" reintegration of traditional family values and reinforcement of heterosexuality, the "witch hunts of the early " 50 s directed against homosexuals spoke to a pervasive fear of Otherness." The influx of women in the labour force and the challenges to the traditional roles articulated by the feminist movement in the mid to late sixties, further contributed to gender anxiety and the need to re-order society along conservative lines $(1996,34)$.

The actions of government within this climate of gender anxiety show a clear relationship to the anti-homosexual campaigns, gender role stability, and the broader goal of social regulation within Canadian society. One productive way to ensure the dissemination and success of these models was through the civil servants - the public face of the nation-state which Canadian citizens should emulate.

As Gentile documents, civil service efforts at social regulation culminated in the creation of the "Miss Civil Service" contest and the Ottawa Man ideal. By stabilizing 
gender roles within the government, these models were an alternate method of ensuring security within the nation-state's civil service. The Miss Civil Service Contest, which began in 1950 and lasted through 1973, created an idealized image of the female government worker and represented "'proper' codes of femininity, beauty, and sexuality in the federal community" (Gentile, 2000, 133). In addition to being a model of femininity to her fellow civil servant workers, Miss Civil Servant was a model of femininity to the Canadian public. Conversely, the Ottawa Man, in keeping with the image of the most powerful male civil servants, was "heterosexual and virile, but not flamboyant" (Gentile, 2000, 138). As such, Ottawa Men were highly educated, well mannered, articulate, and discerning (Gentile, 2000, 137). The contrasts between the ideal government guy and girl were consistent with traditional gender roles.

These beauty contests and the image of Ottawa Man, in conjunction with the anti-homosexual campaigns, stand as powerful proof of the social and sexual regulation that attempted to define proper gender scripts in the Cold War period. While directed at the civil service, public appearances by Miss Civil Service and news articles on the Ottawa Man suggest that these gender ideals were for the consumption of the Canadian public. Even though these campaigns were based in Ottawa, the media publicity surrounding the Ottawa Man and Miss Civil Service suggests that these campaigns functioned both as part of official, state-directed nationalism and also permeated popular, societal discourses around English-Canadian nationalism. Furthermore, the public presence of these models were designed to ease fears of social change by reinforcing traditional values, sex roles, and the pre-eminence of the family within the civil service and Canadian society. While regulating societal norms, the government 
guy and girl marginalized gays and lesbians because of their inability to meet this heterosexual prerequisite and reinforced the compulsory heterosexuality of the nation.

The emerging historical record in this area reveals that Canada's second sexual regime was multifaceted and complex. Moral regulation and urban growth facilitated the spread of submerged gay and lesbian networks that later developed into formidable communities within English Canada. While the secrecy and custom of gay and lesbian associations characterized the lifestyles of homosexuals throughout this period, the Canadian government simultaneously promoted heterosexuality and traditional gender roles with the establishment of civil service gender models and monetary incentives to further the nation-building project. Nation-building was not, however, only concerned with heterosexuality. As the Canadian anti-homosexual campaign reveals, government officials directed great efforts and financial resources into the surveillance, detection, and regulation of gay and lesbian civil servants and emerging gay and lesbian communities. With a frame of restructuring, the modernization of Canadian society and state permitted increased preoccupation with the maintenance of compulsory heterosexuality and rhetoric that insisted on the need for protection of the nation from homosexual influence and activity.

Pryke's analysis helps clarify the differences between the first and second sexual regimes. Early in the second sexual regime, the investigation of "homosexual pathology" supported the regulation of vice and excess by moral reformers. These practices contributed first to the creation of underground networks that eventually developed into public gay and lesbian communities following World War II. The redefinition of the homosexual security risk, during this same post-war period, was 
based on sexual stereotypes of homosexuals as "promiscuous" and "untrustworthy". These "character weaknesses" rationalized the exclusion of homosexuality and the reinforcement of heterosexuality. The alleged "character weaknesses" of gays and lesbians separated homosexuals from ideological security threats (Communists and socialists) and resulted in the increased observation and surveillance of gay and lesbian communities. Although these arguments were placed under the rubric of Cold War threats, the breakdown and specific targeting of gays and lesbians speaks to a larger, multifaceted project with benefits seen as integral to the survival of the nation-state.

The public appearances of Miss Civil Service and the construct of the Ottawa Man reinforced the heterosexuality of Canadian society. They provided models of the ideal gender/sexual roles and traditional values to be emulated by Canadians and provided Canadian citizens at large with a model of who belonged and who did not, most specifically gays and lesbians. Efforts at social and gender regulation during the second sexual regime, therefore, supported the nation-building process that coincided with the Cold War period, the entrenchment of the Canadian welfare state and the solidification of traditional gender roles within Canadian society. Within this context, the anti-homosexual campaigns and the Government Girl/Ottawa Man take on a much more important role, highlighting a backlash against any diversion from the nationstate's attempt to strengthen its heterosexual foundations through support for the traditional family unit. As a consequence, gays and lesbians, framed as enemies of the nation, proved to be a potent threat requiring a multifaceted program of exclusion.

The Third Sexual Regime: Gaining Managed Integration 
The previous two sexual regimes outlined above illustrate the breadth and diversity of sexual regulation within Canada's history. While homosexuals and heterosexuals alike were subject to this regulation, the difference was, however, that sexual regimes construct homosexuals as immoral, deviant, and criminal. This pattern of homosexual exclusion is often assumed to have ceased with the oft quoted statement by former Prime Minister Pierre Elliot Trudeau: "The state has no place in the bedrooms of the nation" (as quoted in Rankin, 2000, 176). Nevertheless, Rankin astutely observes that,

[d]espite the federal government's apparent liberalisation of policies around homosexuality, then, as now, the construction and maintenance of pan-Canadian nationalism demanded that the state remain keenly interested in the bedrooms of its citizens. In fact, the project of defining national identities in Canada has always involved significant attention to the regulation of the sexual preferences and practices of Canadians $(2000,177)$.

While "officially" removing themselves from the bedrooms of the nation in the late 1960s, the Canadian government, in effect, became more involved in the public regulation of sexuality in the $1960 \mathrm{~s}, 1970 \mathrm{~s}$ and $1980 \mathrm{~s}$.

The third Canadian sexual regime coincides with the rapid social change that occurred during the 1960s and 70s. The introduction of modern English Canadian nationalism's pillars, such as multiculturalism, bilingualism, the 1982 Canadian constitution, and the Canadian Charter of Rights and Freedoms, signified the beginning of a new Canadian era replete with a new discourse promoting citizen equality, and perhaps most notably, gender equality. Officials presented the 1982 Canadian Constitution as marking the maturation of the Canadian nation-state and its nationalism. Canada, at least in the eyes of its English Canadian citizens, was now an independent, modern nation that adhered to ideologies of democracy, equality, and freedom for all. 
For gays and lesbians, the most important development was the Charter of Rights and Freedoms and the equality rights it potentially guaranteed.

The Charter of Rights and Freedoms' adoption offered gays and lesbians a new route for pursuing inclusion and belonging within the Canadian community. For many, including the feminists whose successful struggles for sex equality guarantees had opened the door for particularly for lesbians, the entrenchment of minority rights and values of equality and non-discrimination in the Charter was a momentous occasion for those who long felt the exclusion of previous political regimes; yet, the Charter did nothing immediately to acknowledge the discrimination and exclusion of "out" gay and lesbian Canadians, who wished for explicit recognition of their sexual orientation. Section $15(1)$ states,

Every individual is equal before and under the law and has the right to the equal protection and equal benefit of the law without discrimination and, in particular, without discrimination based on race, national or ethnic origin, colour, religion, sex, age or mental or physical disability (Government of Canada, 1999, 568).

The omission of sexual orientation in Section 15 was not unintentional. During the process to amend the British North America Act in 1980, A Special Joint Committee of the Senate and House of Commons was asked repeatedly to include sexual orientation among the enumerated groups within the Charter. In spite of a Liberal Party resolution to champion equality rights on the basis of sexual orientation, this committee voted down the appeal 12 to 2 (Lahey, 1999, 33). One member, so enraged by the attempted inclusion, stated that "Parliament could not "include every barnacle and eavestrough in the Constitution of Canada"' (as quoted in Lahey, 1999, 33). In consolation, it was commonly agreed that the open ended wording of Section 15 , secured secretly by NDP Member of Parliament Svend Robinson (Rayside, 1998, 109), would permit future 
flexibility in rendering court decisions that would be favourable for gays and lesbians. As such, even as 'non-enumerated' groups, gays and lesbians would be able to gain access to equality rights guarantees.

The omission of sexual orientation from the enumerated groups in Section 15 calls into question the potential deconstruction efforts of actors within the third sexual regime. The judiciary's non-inclusive interpretation of Section 15 wording until 1995 is evidence of this point. As a result, gay and lesbian exclusion was prolonged because of the judiciary's strict reading of the apparently "openly" worded Charter clause. In addition, the achievement of sexual orientation being "read" into Section 15 did not accelerate the transfer of gay and lesbian rights through court and/or legislative avenues (Lahey and Alderson, 2004, 74-75). Instead, the status quo of heterosexuality, entrenched by earlier sexual regimes, remained firmly in place.

The inclusion of gays and lesbians that has occurred in the intervening years since the Charter has been slow, piecemeal, and incomplete at best. This trend emulates Walby's (1997) rounds of restructuring discussed above. Read through rounds of restructuring, the sexual regime allowed for the gradual inclusion of those gays and lesbians who have 1) remained single individuals who practice their sexuality within the privacy of their homes or publicly during festivals or celebrations and/or 2) assimilated to the heterosexual majority's relationship models that match the patriarchal and gendered foundations upon which the heterosexual regime relies. Proof of this fact is most obvious in the area of relationship recognition (i.e. partner insurance, pension, and spousal benefits), which allows for the inclusion of gay and lesbian relationships that mimic those commonly accepted within and by the sexual regime. At the same time, the 
benefits of inclusion and belonging continue to elude gays and lesbian who do not match heterosexual relationship models. These non-conformist individuals embrace a publicly announced, displayed, and enjoyed "alternative" gay and lesbian lifestyle of promiscuity, public sex, and deviant sexual acts outside of hetero-like relationships. Thus, the heterosexual foundations of the nation remain intact despite the extension of relationship recognition to gays and lesbians.

As I will demonstrate in Chapter Four, the efforts of actors to deconstruct the third sexual regime through ideologies of non-discrimination, equality and democracy continue. While the current sexual regime does provide entry to certain groups or individuals, it does so on its own terms. For gays and lesbians, inclusion comes at the cost of adopting a "behind closed doors" homosexuality, an acceptable "public" homosexuality, or conforming to heterosexual relationship models and gender roles. Deconstruction efforts, therefore, are incapable of fully dismantling the (heterosexual) foundations that open up room for the true acceptance of sexual diversity that previously existed in North America among indigenous communities. As a result, the current sexual regime promotes limited integration, with the potential for full belonging still unrealized.

While criminal codes were repealed and mechanisms for equality extended to gays and lesbians, full inclusion still remains elusive for these sexual minorities. In effect, gays and lesbians have fought forcefully for equality rights and freedom from discrimination through numerous court and legislative battles to gain, secure, and maintain their rights as fully "out and proud" Canadian citizens. Yet, these endeavours resulted in varying levels of success, continue to be challenged and are constantly at 
risk of being rolled back. As I illustrate in Chapter Four, these events demonstrate the fact that heterosexuality was, and remains, the hegemonic sexuality sanctioned by the English Canadian nation.

Unlike the second sexual regime, the current sexual regime is less concerned with overt regulation and exclusion of gays and lesbians. In contrast, it seeks to protect the Canadian nation-state through the controlled management and integration of once excluded gays and lesbians. The adaptation of the sexual regime occurs because the nation-state can no longer openly regulate sexuality of gays and lesbians. New values entrenched within the Charter of Rights and Freedoms allow citizens of the nation the freedom to do whatever they please behind the closed doors of their bedrooms. However, the public expression of sexuality in the nation becomes the threat to be managed through legislation, rights, and selected exclusion.

Here, common sexual stereotypes of gay and lesbian "deviance" contribute to the slow rate of inclusion through legislation. The repeal of criminal penal codes and acceptance of their sexuality "behind closed doors" did little to rectify the public marginalization gays and lesbians experienced within Canadian society. As discussed above, the reluctance of Canadian politicians and then the judiciary to extend vital Section 15 Charter protections to gays and lesbians was due to their perceived unimportance. Their exclusion was prolonged and justified repeatedly despite the backroom promises of future Charter protections. This sequence of events contradicted the spirit of inclusion and non-discrimination ushered in by Canada's maturation and maintained the compulsory heterosexuality of the nation and its nation-building projects. 
As a result, the deconstruction of the third sexual regime remains incomplete. Limited integration of "acceptable" gays and lesbians still displays a reliance on stereotypes of homosexual deviance and immorality. The slow transfer of rights and piecemeal legal integration of gays and lesbians exhibits the hesitation among many policymakers to reject previous notions of the gay and lesbian threat to the nation. Therefore, the continued marginalization of homosexuals and their relationships demonstrates that attempts to shift the basis upon which nation-building occurs is far from complete.

\section{Conclusions}

This chapter advances an argument for the existence of Canada's sexual regimes over time. I argued that three sexual regimes existed in Canada since European contact. The first sexual regime predated the Confederation and continued to the 1920s. Based on the oppression of Aboriginal sexual diversity and the regulation of colonial sexuality, this first regime was driven by a desire to support and build the new Canadian nation. Gradually, a second regime emerged that relied much more heavily on governmental regulation of homosexuality and promotion of heterosexuality. The creation of the welfare state supplied heterosexual couples with monetary incentives to increase the Canadian population, as well as entrench further the ideal of the heterosexual family with entrenched gender roles. As well, the "Red scare" provided a very convenient guise for the Canadian government and security officers to target and exclude gays and lesbians from the national community. The current sexual regime, I argue, is based on managed integration of gays and lesbians into the national 
community. Inclusion is, however, only guaranteed for those in sanctioned relationship models that mimic those of their heterosexual counterparts.

In spite of the inclusion granted through rights entrenched in Canada's constitution, gays and lesbians still find themselves struggling for the piecemeal transfer of rights that do not fundamentally alter the heterosexual nature of the Canadian nationstate. Rather, I contend that the sexual regime is being extended to include those gays and lesbians that assimilate to models of heterosexual, monogamous companionship. Simultaneously, heterosexuality remains privileged as the societal norm of sexual orientation to which all those who wish to be fully integrated as Canadian citizens should aspire.

Consequently, the three sexual regimes examined show how, despite an undeniable improvement in the rights of gay and lesbian Canadians, nationalism continues to work to exclude and control the inclusion of gay and lesbian "enemies" within the state. This present sexual regime, however, has undergone a major shock with the current debates around same-sex marriage. In the next two chapters, I explore the third sexual regime in more depth and demonstrate its incomplete deconstruction. The next chapter examines the universe of political discourse around same-sex marriage debates and outlines the arguments for and against extending marriage to gays and lesbians. My purpose is to reveal the persistent contestation around issues of sexuality within the Canadian state and society through appeals to nationalism. I also continue to outline the incomplete deconstruction project of the third sexual regime despite concerted efforts to extend belonging to gays and lesbians. 


\section{Chapter 4: Debating Same-Sex Marriage}

\section{Introduction}

The third sexual regime continues to exert influence throughout the Canadian nation-state. Despite the activism of many actors working to end the sexual regime's exclusionary practices, gays and lesbians still find themselves marginalized and viewed differently within Canadian society. The vociferous national debate around same-sex marriage, for example, illustrates the ongoing concern regarding the acceptance of homosexuality in the Canadian nation. This evidence, I contend, reveals the incomplete deconstruction of the third sexual regime. Moreover, the debates call into question the ability of actors to deconstruct completely a sexual regime that is embedded in nationalism. To test these hypotheses, I present a snapshot analysis of the same-sex marriage debates.

With the recent passage of the Civil Marriage Act, Bill C-38, gays and lesbians reached a significant milestone imagined by many as the last step to gaining full equality and belonging within the Canadian community. The purpose of this chapter is to outline the arguments for and against same-sex marriage as presented by various actors within the universe of political discourse. My goal is to show how English Canadian nationalism's pillars were deployed in this contestation over same-sex marriage to sway the opinions of other actors. It is in this process of contestation that the degree and terms of inclusion for gay and lesbian Canadians within the national community were established.

The terrain within which these debates unfold is the universe of political discourse. As discussed above in my methodology section, my use of Jenson's concept 
allows me to capture and analyse discourse from both the state and society, and official and popular nationalism. In seeking to highlight this interaction of state and society, I again attempt to examine the middle ground between these disciplinary constructs. These discourses and debates draw on elements from the previous two sexual regimes. In the second section of the chapter, I explore this history of relationship recognition sought by gays and lesbians in the third sexual regime. Here, I wish to explore the contradiction outlined in the previous chapter regarding the goal of equality for gays and lesbians versus the reality of sustained marginalization. I then outline the engagement of nationalism in the recent debates around same-sex marriage. I trace how the pillars of English Canadian nationalism, specifically equality, rights, the family, marriage, and the courts, were used to gain support for, or build opposition against, same-sex marriage amongst Canadians. As will become evident, both sides of the debate invoke the same pillars of English Canadian nationalism to make their case. However, some were more comprehensive in their approach than others. In Chapter Five, I provide an analysis of these debates, arguments, and ideas to demonstrate the incomplete deconstruction of the third sexual regime in Canadian society and to argue my thesis that English Canadian civic nationalism contributes to the exclusion of gays and lesbians within the national community.

On a final note, I recognize that my concentration on marriage is only one part of the attempted deconstruction of the third sexual regime. I feel that the institution of marriage, however, has been defended vociferously by the federal state through its discriminatory regulation of marriage's heterosexual definition to ensure the exclusion of homosexual couples. Consequently, the same-sex marriage debates mark a 
significant moment of perceived threat for the English Canadian nation-state which, until this point, has been successful at maintaining marriage as a heterosexual institution to safeguard the future Canadian nation-state from the acceptance and inclusion of homosexuals and their relationships.

\section{Fighting the Long Fight: Searching for Relationship Recognition}

As discussed above, the same-sex marriage debates are situated within a historical context which informs the current discussions on the topic. In Chapter Three, I sketched the first and second sexual regimes that contribute to the contemporary universe of political discourse. History continues to influence the present and it is important to trace the continuing strength and fluidity of sexual regimes, because they build upon one another rather than replacing their predecessor. In this section, however, I will focus on the current third sexual regime and specifically court-based challenge and activism for relationship recognition.

Key to Canadian gay and lesbian struggles for equality and belonging is a quest for the recognition and acceptance of their sexuality and relationships by government, the courts, and Canadian society. As legal theorist Douglas Sanders observes, “...[E]quality for same-sex couples involves a public recognition of homosexuals, equal to the public recognition the State and society accords heterosexuals by the recognition of heterosexual relationships" $(1994,121)$. The emergence of a right-based equality seeking framework to deconstruct the third sexual regime created space within the universe of political discourse in which lesbians and gays could assert their presence and make known their experiences of social marginalization. From the beginning, gay 
and lesbian activists recognized that full relationship recognition would involve access to marriage on a level equal to that of their heterosexual counterparts.

In 1974, Richard North and Chris Vogel made the first unsuccessful attempt to secure a marriage license (Warner, 2002, 223). Their judicial appeals were rejected because of the traditional heterosexual definition of marriage (Sanders, 1994, 132). This definition and understanding of marriage as the bond between a man and a woman thwarted the efforts of gays and lesbians to enter the state sanctioned institution legally. Governments continued to rely on a heterosexual definition of marriage to justify the discrimination and exclusion of gays and lesbians from marriage until 2003 (Lahey and Alderson, 2004, 24). In large part, the heterosexual definition relied heavily upon the potential of procreation in heterosexual marriages (Sanders, 1994, 133). As a result, these two arguments were often intertwined in dissenting judgments against gay and lesbian couples' right to marry (Lahey and Alderson, 2004, 24).

In addition to exclusionary heterosexual marriage definitions, government actions sought to ensure that marriage remained the sole domain of heterosexual Canadians. Throughout the 1970s and 1980s gender equality project, the practice of introducing gender neutral language that inferred opposite sex relationships, such as 'opposite sex spouse' and 'opposite sex cohabitant,' became commonplace within Canadian legislation (Lahey and Alderson, 2004, 24-27). The exclusionary legislative measures adopted at the provincial and federal levels made achieving recognition for same-sex relationships particularly difficult and time consuming. Even with the positive ruling in the 1995 Egan and Nesbit case recognizing the infringement of spousal definitions as only opposite sex, courts still upheld the exclusion of gays and lesbians 
because discrimination was still justifiable according to societal norms (Hurley, 2003; Lahey, 1999; Lahey and Alderson, 2004; MacDougall, 1999; Rayside, 1998; Warner, 2002).

These judicial tendencies continued until the M. v H decision in 2000. In this decision, the Supreme Court ordered governments to correct all discriminatory definitions in Canadian family law. While adhering to the M. v H. decision, the House of Commons adopted a motion that restated the heterosexual definition marriage and charged Parliament with the duty to "take all necessary steps to preserve this definition of marriage in Canada" (Hurley, 2003, 26). Bill C-23, which extended common law status to gay and lesbian couples, was amended to ensure marriage remained heterosexual. Politicians reasserted the definition of marriage as the "union of one man and one woman to the exclusion of all others" (Hurley, 2003, 27). While gay and lesbians activists' success in the courts increased significantly after Egan and Nesbit, government commitment to protecting marriage revealed an unwillingness to extend equality to homosexual Canadians. As governments began to recognize the equality of same-sex common law relationships, however, it became harder to justify the protection of marriages from gay and lesbian couples (Lahey and Alderson, 2004, 78).

The slow recognition of same-sex relationships inspired activists within the gay and lesbian community to take the final step in search of relationship recognition. Shortly after the M. v H. decision in 2000, activists in British Columbia, Ontario and Québec launched court cases to challenge the heterosexual definition of marriage. The cases disputed the constitutionality of marriage definitions that prohibited gays and lesbians from solemnizing their relationships. In 2001, the British Columbia Supreme 
Court ruled that the traditional definition of marriage did not contravene S.15 of the Charter. In dismissing the activists' challenge, the trial judge reasoned that changes to common law, such as amending the definition of marriage, should be made in incremental steps. Moreover, Judge Pitfield ruled that Parliament could not change the definition of traditional marriage to include same-sex couples, which at the time of Confederation only recognized opposite-sex couples. He concluded that even if Section 15 was applicable, the heterosexual definition of marriage was demonstrably justifiable under S.1 of the Charter (Hurley, 2003, 17). This decision was appealed by Equality for Gays and Lesbians Everywhere (EGALE) and the gay and lesbian couples who petitioned for the change.

Initial Ontario and Québec Supreme Court decisions delivered in 2002, disagreed with the earlier BC Supreme Court ruling. Both these courts found that the definition of marriage as solely heterosexual did contravene Section 15 of the Charter. They added that maintaining these exclusionary definitions or instituting a similar "marriage-like" institution would be a "separate but equal" situation that would be vulnerable to constitutional challenges in the future (Hurley, 2003, 18). As a result, both the Ontario Supreme Court and the Cours supérieure du Québec delayed the implementation of same-sex marriage for a period of 24 months to allow federal and provincial governments to bring their laws into line with the decisions rendered. The Ontario and Québec decisions were appealed by the Government of Canada.

In 2003, the Ontario Court of Appeal's decision changed the definition of marriage in Canada forever. The decision handed down on July 10, 2003 supported the previous ruling of the Ontario Supreme Court, which ruled that maintaining a 
heterosexual definition of marriage contravened S.15 of the Charter of Rights and Freedoms. The court then made the unusual decision to modify the Ontario Supreme Court's remedy and invalidate the exclusionary definition of marriage, allowing samesex marriages immediately (Lahey and Alderson, 2004, 86). A month later, the British Columbia Court of Appeal, which reversed the decision of the BC Supreme Court and set a date of July 12, 2004 for same-sex marriages to become law, changed the previous timetable for the introduction of marriage, instituting it immediately as of July 8, 2003. The Québec Court of Appeal soon followed suit allowing same-sex marriages to take place simultaneously with their decision delivered March 19, 2004.

The sequence of events outlined above reveals the legal contestation over sexuality within the Canadian nation-state and the ongoing contestation over gay and lesbian relationship recognition. Within the context of relationship recognition, the deconstruction of the third sexual regime is demonstrated by the partial acknowledgement of gay and lesbian relationships. At the same time, they expose governments' willingness to include homosexuals in some contexts (common law relationship status) and reinforce exclusion in others (marriage). The same-sex marriage debates outlined in the following sections flow from the judicial decisions in Ontario, British Columbia, and Québec which extended marriage to gays and lesbians. Because the courts amended the traditional definition of marriage with gender neutral language, federal politicians then faced the task of reconciling government legislation with the court-ordered definition of marriage. Out of this need for reconciliation, actors for and against same-sex marriage asserted their positions in an effort to influence public 
opinion and gain legislative change or protect the status quo in keeping with their vision of the Canadian nation.

\section{They're Just Not the Same: Families, Marriage and Homosexual Deviance}

The debate against same-sex marriage relies on vital pillars of the Canadian nation and nationalism, such as marriage, the family, and the deviance of homosexuality. Opposition arguments concentrate on stressing the alleged deviance and immorality of homosexuality; portrayed as unworthy and immoral individuals, gays and lesbians are argued to be undeserving of the right to marry and create families of their own. In this section, I explore the links between homosexual deviance, the institution of marriage, and the family as presented by those who insist marriage should remain the sole domain of heterosexuals.

The crux of the arguments against same-sex marriage is the perceived lack of morality among gays and lesbians. From documents accessed on pro-traditional marriage group websites, it becomes abundantly evident that the alleged immorality of homosexuality is the central mobilizing factor behind the urgency to stop the extension of marriage rights to gays and lesbians. The website for REAL Women of Canada, an anti-feminist women's organization that supports solutions for women that takes into account their impact on the family and society as a whole, provides an excellent example of the connections made by opposition groups to frame arguments against same-sex marriage in a deviance discourse that points to "credible" medical and scientific data. In a publication from their website entitled "'Gay marriage' and 
homosexuality: some medical comments," REAL women outlines some of the reasons why gays and lesbians should not be permitted to marry.

First, the document justifies withholding marriage rights on statistical grounds. It states,

Despite the impression given by the media, the actual number of homosexuals is quite small. Essentially all surveys show the number of homosexuals to be only $1-3 \%$ of the population. The number of homosexuals living in 'common law relationships' is even less, only $0.5 \%$ of all couples.... The pressure for introducing same-sex marriage comes from a very small section of society (Real Women of Canada, 2005).

This justification is supported by "facts" on the "health risks of the homosexual lifestyle." Here, the document lists the "large number of very serious physical and emotional health consequences" of homosexual activity (Real Women of Canada, 2005). These risks include: high levels of sexual promiscuity within same-sex relationships; short duration of committed homosexual relationships; high risk sexual practices, like anal sex; high rates of sexually transmitted diseases, and increased rates of mental illness among the homosexual population (Real Women of Canada, 2005). All of these potential health risks are corroborated with decontextualized "facts" from various American, British and Canadian associations, government departments, and academic studies.

Such rationales permeate the public positions articulated by politicians opposed to same-sex marriage. The most obvious example of "homosexual deviance" thinking was the 2002 outburst of Elsie Wayne, former deputy leader of the Progressive Conservative Party. In the House of Commons, Wayne was recorded as saying,

If they are going to live together, they can go live together and shut up about it.... There is not any need for this nonsense whatsoever and 
should not have to tolerate it in Canada.... Why do they have to be out there in the public always debating that they want to call it marriage? Why are they in parades? Why are they dressed up as women on floats? They do not see us getting up on floats, for heaven's sake, to say we are husband and wife. We do not do that. Why do they have to go around trying to get a whole bunch of publicity? (Lunman, 2003b, A4). ${ }^{14}$

She continued in a later interview to say, "It shouldn't be marriage....If they want a union, it's up to them. That's it. Glory be to God to live in Canada, marriage in man and woman" (Lunman, 2003b, A4).

The sentiments of Wayne reflect the continuation of efforts by some to marginalize the homosexual population from the larger Canadian community. Such constructions marked the debates around same-sex marriage forwarded by both Conservative party members, like Wayne, and members of the governing Liberal party. For example, former Solicitor General of Canada Wayne Easter voiced his personal concerns with the Liberal adoption of the new marriage definition in 2003. He said, "There is a difference between heterosexual couples when they get married; it's procreation....That can't happen with same-sex couples" (Taber, 2003a). Here, the threat that homosexuality poses when entrenched within a fundamental institution such as marriage to opponents of same-sex marriage is apparent. Once again, homosexual "difference and deviance" arguments were deployed to substantiate opposition arguments regarding the preservation of marriage as a heterosexual institution.

For opponents of same-sex equality, marriage is extremely important to Canadian society. The foundational role of this institution to the well-being of the nation is well documented within opposition debates around same-sex marriage. In an

\footnotetext{
${ }^{14}$ Wherever possible, I take direct quotations from the sources analysed. In cases where quotations were not available, I have cited the article and acknowledged the reporter's role in paraphrasing the speaker's comments.
} 
essay entitled "Can This Marriage be Saved?" Lorna Dueck, a popular Canadian Christian author and broadcaster, states "the definition marriage is at the core of our ideas of individual and religious freedoms; it's shaped by moral standards that have stood for centuries" (2004) Opponents of same-sex marriage argue that gays and lesbians desire the legitimacy that comes with this sacred social union: "It is because marriage is valued and bears social legitimacy that gays and lesbians want to be considered as married" (Clemenger, 2003). For these actors, the institution of marriage is central to the preservation of Canadian society. In this line of thinking, the key to maintaining the heterosexual institution of marriage, however, is to deny the privilege of marriage to homosexuals.

This opinion is shared by many church leaders and Canadian religious groups, who spoke out against same-sex unions. In 2003, an edict was issued to Catholic politicians on the issue of same-sex marriage. The document, a reiteration of prior statements against the legal legitimization of homosexual unions, called upon Catholic politicians to follow the precepts of their faith and protect the Creator's gift of marriage. The edict states,

Marriage is not just any relationship between human beings. It was established by the Creator with its own nature, essential properties and purpose. No ideology can erase from the human spirit the certainty that marriage exists solely between a man and a woman, who by mutual personal gift, proper and exclusive to themselves, tend toward the communication of their persons. In this way, they mutually perfect each other, in order to cooperate with God in the procreation and upbringing of new human lives (Ratzinger and Amato, 2003).

Defined as such, marriage becomes the sole domain of heterosexual couples. It continues,

There are absolutely no grounds for considering homosexual unions to be in any way similar or remotely analogous to God's plan for 
marriage and family. Marriage is holy, while homosexual acts go against the natural moral law. Homosexual acts close the sexual act to the gift of life. They do not proceed from a genuine affective and sexual complementarity. Under no circumstances can they be approved (Ratzinger and Amato, 2003).

These doctrines from the Vatican entered public debates in Canada through open letters written to the Prime Minister and Catholic parishioners by Catholic Bishops. One letter by Calgary Bishop F. B. Henry argues,

The committed union of two people is not the same human reality as the committed union of one man and one woman. A same-sex union is not a physical union that transmits human life, producing children. A same-sex union is not the joining of two complementary natures that complete each other. Simply stated, a same-sex union is not a marriage. The idea that homosexuals can create same-sex "marriage" through their individual choice is false (2005).

These reiterations of Catholic doctrine from the Canadian Catholic clergy formed an influential presence within the debates on same-sex marriage and, in turn, strengthened the position of many other religious groups who issued similar statements to the federal government regarding same-sex marriage. ${ }^{15}$

These calls from the religious leaders, conservative political and religious groups clearly influenced debates on same-sex marriage. Sympathy and support came from both sides of government. For example, Pat O'Brien, an outspoken Liberal member opposed same-sex marriage, became very well known for his views about the place of traditional marriage within Canadian society. In an interview with CBC Radio in 2003, O’Brien stated,

Don't tell me Ralph and Bob being together is marriage because to me it's wrong.... If you're going to throw open the definition of marriage so you destroy it in essence, how do you know you can ever draw the

\footnotetext{
${ }^{15}$ It must be noted that there are religious groups and sects that have issued support for same-sex marriage. These groups include the United Church of Canada, Unitarians, and certain Anglican dioceses, who have agreed to recognize same-sex unions, but stop short of marriage due to their religious doctrines which frown upon homosexuality. The Metropolitan Church of Toronto always supported same-sex marriage and was even granted intervener status in the Supreme Court reference in 2004.
} 
line any place? If I want two or three wives and want that considered marriage, who are you to tell me I can't? (CBC News Online Staff, 2003c).

O'Brien's sentiments engendered increasing support among some provincial Premiers. Former Ontario Premier Ernie Eves, for example, voiced his opposition to same-sex marriage publicly in August 2003. Drawing upon his religious upbringing, Eves stated that "he doesn't personally support for [sic] gay and lesbian marriages.... I personally believe in heterosexual marriages" (Canadian Press, 2003a). Alberta Premier Ralph Klein reiterated Eves' feelings in 2004. Klein's position was that gays and lesbians do deserve protections in many areas; however, same-sex marriage is not considered among them. He went on record as saying,

I have friends who are gays and friends who are lesbian and they're wonderful people.... I do feel that gays and lesbians ought not to be discriminated against in any other form other than marriage, because marriage is a sacred thing that exists between a man and a woman (CBC News Online Staff, 2004a).

All three men waded into the debate on same-sex marriage utilizing moral discourses about homosexuality to justify the exclusion of gays and lesbians from the institution of marriage. For each man, marriage is a union between a man and a woman to the exclusion of all others such that same-sex marriage would irrevocably destroy the institution. These politicians incorporated the logic and ideals of both conservative and religious groups in their opinions against same-sex marriage, thereby fuelling a discourse which fused the decay of the Canadian nation with the redefinition of marriage.

Opponents of same-sex marriage also invoked the family and children to support their case for the maintenance of heterosexual marriage. In the Vatican's edict, one of the main purposes of marriage is defined as "the procreation and upbringing of new 
human lives" (Ratzinger and Amato, 2003). Catholic Cardinal Ambrozic, in his open letter to the Prime Minister, drew a direct link between marriage and the family when he wrote, "The conjugal partnership of a man and woman is the beginning and basis of human society, and the family is the first and vital cell of society" (Ambrozic, 2005, A19).

The important links between the family and marriage were expanded upon in an article on the Defend Marriage website,

The social magic about marriage is that it provides the ideal environment for the nurture of the rising generation. Children who grow up in a home with their married mother and father are healthier, more successful in school, more confident, more likely to avoid drugs, and less likely to suffer depression, poverty or abuse, to exhibit behaviour problems, to commit suicide, or to go to jail than are children from any other type of home. They are also more likely to form stable marriages in adulthood.... Marriage, then, serves everyone by fostering stable families. It isn't the only means of launching a family (people are free to join their lives and raise children in a variety of other) forms, but its special legal status allows the government to protect and uphold it, to the benefit of all society (Defend Marriage Canada).

For opponents of same-sex marriage, the heterosexual nature of marriage is the cornerstone of the Canadian family. Without the protection of marriage as a heterosexual institution, the family and children are in jeopardy. Following this line of thinking, the protection of children factors prominently into discussions around samesex marriage and its impact on a child's right to be raised in traditional families.

As ethicist Margaret Sommerville has argued,

The same-sex marriage debate has focused on the rights of gay adults. But what about the rights of children? Do children have a basic right to know who their biological parents are and to be brought up by them? Does society need an institution that establishes that right as one of its basic principles and norms? If our answer is "yes," then we must say "no to changing the definition of marriage to include samesex couples (2003, A15). 
Here, the child's rights take precedence. As conservative thinker, D. Anne Castle, a single mother and dual citizen of Canada and the United States observed, "the most government can do is promote parental responsibility by upholding marriage - the only institution in the world that secures a mother and a father to every child born within it. This is, in fact, the entire basis for the state's interest in marriage. (Castle, 2003)"

Unlike the previous discourses of "homosexual deviance" and marriage as a fundamental institution, arguments centered on the family and children were not widely accepted by politicians as a reason to deny gays and lesbians marriage rights. The need to protect a child's right to be raised in a traditional family is undercut by the reality that Canada's children grow up in a variety of families. Not only has the traditional family been broken down by divorce and separation, but single parent families have also grown in number. Furthermore, the appearance and slow recognition of same-sex families contributes to Canada's diverse families (Arnup, 2001, 35-38). Nevertheless, the traditional family in conjunction with the other two discourses advanced by opponents of same-sex marriage together weave a powerfully convincing opposition discourse that complicated gay and lesbian struggles for marriage rights (Harvey, 2004, A1).

\section{Arguing Against Same-sex Marriage: Courts, Rights, and Mitigating the Effects of Change}

Debates around same-sex marriage also focused on the role of rights and courts in Canadian society. As discussed above, the use of courts by gays and lesbians has been quite fruitful. Accordingly, the courts raised the ire of same-sex marriage opponents because of the perceived willingness of the courts to open marriage to gays and lesbians without the counsel of politicians. This discussion outlines the ways in 
which opponents of same-sex marriage endeavoured to delegitimize the courts, renegotiate the meaning of rights, and moderate the effect of same-sex marriage in Canadian society.

The judiciary in Canada must uphold the principles of the Charter of Rights and Freedoms within Canadian society. This role made the court a target for delegitimization attempts by opponents of gay and lesbian relationship recognition. Following the Ontario Appellate Court ruling, for example, opponents objected vociferously to the decision. The perception of judicial arrogance emerged amongst opposition activists and political elite alike. For example, Liberal Pat O'Brien stated, "It's incredibly arrogant of three Ontario judges to change something as fundamental as marriage" (Rowstow, 2003).

The Ontario Appellate Court decision fuelled debate on the judiciary's role in Canada's democratic system. Evidence of this discourse is witnessed in the New Brunswick government's decision to maintain the traditional definition of marriage until a federal bill changing that definition was passed (Canadian Press, 2003b). The sentiment is observed further in the comments of politicians who felt the courts overstepped their bounds. Pat O'Brien stated, "Who's going to have the final word in this country, the elected representatives of the Parliament of Canada, or some appointed, unallocated judges?" (CBC News Online Staff, 2003a). Similarly, Liberal MP Brenda Chamberlain said, "We [the Parliament] just laid down and said whatever the courts say....What about what the people say?" (Clark and Lunman, 2003).

These reactions were echoed by Liberal MP Roger John Gallaway, who put a societal spin on this argument, calling the decision, 
...a terrible attack on the democratic principles in Ontario.... Ontario members have been disenfranchised. When they are disenfranchised the people they present have been disenfranchised, and they have been disenfranchised because the courts have made policy in law and the cabinet cares not to defend the institution of Parliament (Taber, 2003a).

Galloway's comments link the decision of the court to democratic principles upon which the Canadian nation is based. Through their disenfranchisement by the courts, some politicians feared they would be forced to face with the wrath of the public. Public discontent might then result in lost parliamentary seats and reduced political power in Ottawa for the Liberal Party.

Canadian Press journalist Jim Brown explored the question of judicial activism. He observed that "[f]ew issues since the advent of the Charter of Rights and Freedoms in 1982 have so clearly illustrated the tensions between the people who make the laws and the judges who interpret them" (Brown, 2003b). The Ontario decision that struck down marriage laws, and allowed gays and lesbians to marry forced parliamentarians to deal with same-sex marriage on their own schedule after adequate public consultation. That the same-sex marriage issue raised the question of judicial legitimacy is not unusual. This is especially true when one considers the other issues of equality that have been significant catalysts for accusations of judicial activism, such as abortion and gender equality. Thus, criticisms of judicial activism undermined the legitimacy of the courts and their decisions to change the definition of marriage in Canada.

As the legitimacy of the courts was questioned, discussions regarding the nature of equal rights, how they should be interpreted, and whether or not exclusion is justified in the case of same-sex marriage unfolded. In 2003, much of the debate on rights presented by opponents to same-sex marriage revolved around the meaning of equal 
rights. An illustration of the shift in definitions of equality rights is illustrated by the actions and words of Liberal MP Clifford Lincoln. A proponent of equal rights, Lincoln made an impassioned plea in 1998 for equal rights in the context of the French-English language issues in Québec during the Bill 101 debates. At that time he reportedly stated,

In my belief, rights are rights are rights.... There are no partial rights. Rights are fundamental rights.... Rights are links in a chain of fundamental values that bind all individuals in a society that wants to be equitable, and just, and fair. Rights are a bridge that unite people in a society through a set of fundamental values, and the minute you deny those rights, you withdraw that bridge, and create a gap between members of that society by denying those fundamental rights that bind them together (Taber, 2003b).

Around issues of same-sex marriage, however, Lincoln's views shifted considerably. In another equally impassioned plea, Lincoln allegedly said to the Liberal caucus, "rights to be equal don't have to be identical," and that definitions have the capability of discriminating (Taber, 2003b). Lincoln's dissent came from the government's acceptance of court rulings on same-sex marriage. Instead, he reportedly felt that the rulings which "denied parliamentarians [a] chance to explore the definition of marriage" should be appealed (Taber, 2003b). Here, the re-imagination of equality rights is crucial. This event demonstrates that for some equality rights for particular groups, like French Canadians, are fundamental, while for others, like gays and lesbians, they are negotiable. All the while, the results of equality rights, in the minds on Lincoln and others, continued to deny differential treatment which would allow gays and lesbians to marry.

In addition to the renegotiation of equality rights, arguments to justify the exclusion of gays and lesbians from the equality rights guaranteed by the Charter of Rights and Freedoms were also voiced. As outlined above, many, most notably Alberta 
Premier Ralph Klein, felt that gays and lesbians should be protected from discrimination; simultaneously, they also felt that exclusion from the right to marry is justified because of its special role and function within Canadian society (Blackwell, 2005, A1). Calgary's Catholic Bishop Fredrick Henry supported this position and argued that, "[t]he denial of the social and legal status of marriage to same-sex couples is not discrimination. It is not something opposed to justice; on the contrary, justice requires such an opposition" (CBC News Online Staff, 2005a). More recently, it was suggested that gays and lesbians "were not facing discrimination because there was no law saying they could not marry, provided they marry someone of the opposite sex" (Galloway, 2005). The lengths to which certain Canadian politicians have gone to delegitimize or reinterpret the extension of marriage rights illustrates the ongoing contestation concerning sexuality within the English Canadian nation.

In addition, changes to the regulation of marriage to minimize the damage of same-sex marriage on Canadian society were proposed by many within the House of Commons as well. One proposal included the Government of Canada completely abdicating their role in the regulation and solemnization of marriages within the country. Former Progressive Conservative Party leader Peter MacKay advanced this position. His plan proposed that provincial and federal governments introduce a registered domestic partnership for both heterosexuals and homosexuals and leave the solemnization of marriage solely to churches (Clark, 2003). While widely popular across party lines, the Liberal executive did not adopt MacKay's compromise because the courts had ruled previously such an option would be open to constitutional challenge as a "separate but equal" situation (Hurley, 2003, 18). 
These actions precipitated a shift in discourse to ensure that same-sex marriage's impact on religious institutions was limited. Here, protection of religious freedom for churches became the main concern of parliamentarians and opponents of same-sex marriage alike. In 2003, Jean Chrétien stated, "There is an evolution in society, but what is important to me is the freedom of the churches" (CBC News Online Staff, 2003b). While acknowledging the evolution of Canadian society, there was still a sense among leaders that churches required protection from an infringement on their rights to religious freedoms. In 2004, Conservative leader Stephen Harper sought to reframe same-sex marriage debates to guarantee that protections in the tabled same-sex marriage legislation were strong enough to shelter "religious groups from having to perform same-sex marriages if it runs counter to their conscience" (Laghi and Harding, 2004). Again, this series of events illustrates the attempts made to limit the impact of same-sex marriage on Canadian society.

To summarize, opponents of same-sex marriage made effective use of several constructs important to the nation and its nationalism, such as heterosexuality, marriage and the family. As I outline above, the "deviance of homosexuality" formed the crux of opposition arguments to same-sex marriage. Concerns regarding the sacred and important nature of marriage to Canadian society were predicated on the heterosexual nature of the institution. Allowing gays and lesbians to marry, it was argued, risked threatening a foundational institution upon which Canadian society relies. The importance of marriage was underscored by a focus on the families marriage produces. As the central element in nation-building, children deserved the opportunity to be raised in environments that ensure their social respectability and replicate heterosexual values. 
Opponents of same-sex marriage insisted that, like marriage, the future of traditional family, therefore, would be ruined without the government's defence of marriage.

Furthermore, opponents of same-sex marriage sought to delegitimize modern national institutions to advance their case against same-sex marriage. Discourses on the topic of judicial activism, attempts to renegotiate the meanings of equality rights, and ongoing protection of religious groups and marriage illustrate the efforts of actors to maintain gay and lesbian exclusion within the Canadian political system. To a large degree, these oppositional voices have been very successful, despite the passage of Bill C-38. Opposition messages, for the most part, have received ongoing support from the Canadian public. Proof lies in January 2005 poll results which showed Canadians are supportive of gay and lesbian rights, but that sixty-six percent still wished to see marriage preserved as a heterosexual institution (Blackwell, 2005, A1). Such efforts contradict the goals of those actors working to deconstruct the third sexual regime.

\section{Love is Love: Talking Rights and Canadian Values}

The arguments advanced by same-sex marriage supporters are distinct from those of opposition activists in that their rationale links support of same-sex marriage with Canadian values of equality, non-discrimination, difference from the US, and societal evolution. These debates are shaped by activists who have long sought the recognition of their relationships and the right to marry. Organizations, such as EGALE and their same-sex marriage wing, Canadians for Equal Marriage (CEM), assumed a lead role in these struggles, becoming the voice for gay and lesbians Canadians in both 
the media and amongst the public. These organizations centre their arguments firmly within the language of third sexual regime's deconstruction - rights talk.

Rights talk is a central part of the struggle for same-sex marriage that emerged with the entrenchment of the Charter. It is a political discourse that is American in origin and,

privileges the law and the courts as a mechanism for the resolution and processing of political problems such as conflicts of interests and values between groups and the state....[P]olitical actors are engaged in rights talk when they assume that victories before the courts and changes in law will ensure rights protection (Smith, 1999, 74-75).

As a consequence, much of their activism focuses on issues of human rights and the pursuit of gay and lesbian rights in Canada that allows for differential treatment to achieve equal results and establishes that no right is unconditional. For example, in response to a 2003 private member's bill which sought to restrict access of gays and lesbians to civil marriage, John Fisher, spokesperson for Canadians for Equal Marriage stated, "If opposite-sex couples can marry in a civil ceremony and same-sex couples cannot, that's discrimination.... The courts agreed on that" (Canadians for Equal Marriage, 2003a). Alex Munter, national co-chair of Canadians for Equal Marriage added, "Same-sex marriages are now, and will always be, legal in two provinces which make up half of the population of Canada" (Canadians for Equal Marriage, 2003a). Both of the above quotations illustrate the vocabulary which is integral to the rights talk discourse and evoked most commonly through reference to the language of equality, discrimination, and sameness.

Although gay and lesbian activists relied upon the values and language of equality and non-discrimination in their rights talk, concrete rights are referred to solely in conjunction with the government and politicians. For example, in response to Justice 
Minister Irwin Cotler's decision to refer same-sex marriage draft legislation to the Supreme Court of Canada, a regional spokesperson for CEM stated,

Mr. Cotler is a human rights leader with a record of speaking out in favour of the equality of gays and lesbians. It would be a huge let down and a tarnish on his reputation if he were to change his mind and relegate gays and lesbians to the back of the bus.... He should know the problems of singling out any minority for differential treatment (Canadians for Equal Marriage, 2003b).

This particular quotation demonstrates the appeal to rights when addressing the government or legislation. At the same time, the use of rights becomes focused not only on the domestic environment but also assumes an international dimension in terms referencing gays and lesbians as part of a global human rights lobby, linked to the Civil Rights movement in the United States with the reference to the Rosa Parks bus incident. In contrast, when dealing with their fellow Canadians, the arguments from gay and lesbian activists are purposely placed at the level of values, equality, and nondiscrimination or rights talk.

For gay and lesbian activists, the use of rights talk assumes a dual purpose. First, rights talk easily communicates the goals of activism to the English Canadian public. Non-discrimination and equality are values that have a resonance among the English Canadian public in the context of the modern English Canadian nation. Second, this political discourse provides a means for communicating with politicians in an understandable language. Explicit references to rights in a context which acknowledges the role of Parliamentarians as protectors of human rights pressures government to act accordingly to maintain its reputation. Consequently, rights talk has effectively compelled government to recognize the rights-based arguments for same-sex marriage. 
Rights-based arguments are generally accepted amongst politicians and political parties supportive of same-sex marriage. The New Democratic Party (NDP) under leader Jack Layton, is fully supportive of same-sex marriage as an issue of rights that are fundamental to Canadian society and the protection of its minorities (CBC News Online Staff, 2003d). After a failed parliamentary vote to protect the tradition definition of marriage and permit the use of the notwithstanding clause, which has never been invoked in the case of denying rights, former NDP Member of Parliament Svend Robinson stated,

Where has Paul Martin been on the issue of fundamental equality and
respect for the Charter of Rights... Move on it now - this is a
fundamental issue of equality.... You've got a signal today from
parliament that a majority of parliamentarians reject the use of the
notwithstanding clause, that rejected an attempt to reaffirm the
unconstitutional definition of marriage (Muthadie and Dunfield,
2003).

Similarly, the Bloc Québécois is also equally supportive of same-sex marriage as an issue of rights. During debates regarding the possibility of a national referendum on the issue, Gilles Duceppe was reported as saying, "We are speaking of rights... A society has to be excessively vigilant of the rights of its minorities" (Clark, 2004). Nevertheless, these two parties, while fully supportive of gay and lesbian equality and same-sex marriage, include those who dissent on religious or moral grounds, but overall Bloc Québécois and NDP opposition is minimal.

As the governing party during the same-sex marriage debates, the Liberals officially supported same-sex marriage as an issue of fundamental equality rights. In doing so, both Prime Ministers Chrétien and Martin relied heavily on the Charter of Rights and Freedoms and its equality guarantees. Each government drew on the Charter in debates on same-sex marriage to rationalize their positions on same-sex marriage at 
the federal level. As former Justice Minister Martin Cauchon wrote in the Globe and Mail,

The Charter has had an important role in defining who we are as Canadians. We must remember, however, that the Charter was not put in place by judges. Its adoption was a political decision following a full debate in Canada's Parliament. Since then, our courts have played their role in ensuring the guarantees are set out in the Charter are respected (2003).

Here, the presentation of the Charter as a fully vetted Canadian document representing Canadian democracy is designed to appeal to a sense of national pride. Cauchon continues, "As a society, we believe in equality - equal rights despite difference in race, language, gender, or sexual orientation" (2003). A few days later, Cauchon was quoted as saying,

[Gays and lesbians] are entirely part of the society....In telling them that their union doesn't have less value than a heterosexual union, that their love doesn't have less value than the love of a heterosexual couple, that their family doesn't have less value, that their kids don't have less value as well. It's a question of dignity (Laghi, Lunman et al., 2003).

The equality guaranteed by the Charter of Rights and Freedoms gives dignity to those who have been considered as "other" or excluded within Canadian society. As a result, same-sex marriage legislation is framed as the pursuit of fundamental equality for gays and lesbians within Canada.

Supporters of same-sex marriage also relied on appeals to the maturation of the Canadian nation. As discussed in Chapter Three, the patriation of the Canadian Constitution and the entrenchment of the Canadian Charter of Rights and Freedoms stand as recent moments of nation-building for Canada. Together, they are synonymous with the Canadian identity, values, and nationalism. As Richard Nimijean's (2005) work reveals, recent liberal governments in particular have promoted the idea that to be 
Canadian requires one to "act Canadian" and adhere to Canadian values of nondiscrimination, tolerance, and the celebration of Canada's diversity as the "Canadian Way."

Same-sex marriage supporters attempted to place the marriage legislation within this discursive context and framed Bill C-38 as signifying Canada's maturation as a tolerant and inclusive society. This was highlighted most vigorously by Former Prime Minister Jean Chrétien who defended his support for same-sex marriage saying, "there is an evolution in society" and such progress of evolution requires an ongoing reevaluation and expansion of Canadian values. The imagery deployed by Chrétien to label opponents of same-sex marriage as "un-Canadian" raised their ire and resulted in calls on Chrétien to stop "using the courts to cloak his political agenda of advancing gay rights while smearing those who object as un-Canadian" (Brown, 2003a).

Arguments appealing to the values of equality and rights employed by those who support same-sex marriage relied on the language, imagery, and equality legislation to deconstruct the third sexual regime. The use of these national ideas is significant for it shows that like opponents to same-sex marriage, politicians are influenced by the ideas of grassroots activists and citizens. The resonance of rights and equality-seeking frameworks facilitated co-operation between activists and politicians to forward the cause of same-sex marriage to Canadian citizens. At the same time, the engagement of rights, right talk, and equality discourse allow for a broader engagement of Canadians. Gay and lesbian activists convincingly linked the issue of same-sex marriage to global human rights struggles through popular discourse and national imagery with reference to preceding civil rights movements, and the values of equality, 
tolerance, and non-discrimination that are said to lie at the core of our Canadian identity, nation and nationalism.

\section{Resignation and Compromise: Reconciling Canadian Tensions}

As I explored above with respect to opposition movements, discourses to temper the societal change of same-sex marriage legislation were forwarded by proponents of same-sex marriage as well. Although rights remained a central speaking point for both Prime Ministers, equality frameworks served to cloak their discomfort and/or reluctance to forward the cause of gay and lesbian marriage. This reluctance was due in large part to their Catholic faith, which, as presented earlier, does not condone homosexuality or same-sex unions.

For Chrétien, rights and equality frameworks defined his position as the Prime Minster of Canada. During an attack on his religiosity by leaders of the Catholic Church, he observed: "When I'm Prime Minister of Canada, I'm acting as the person responsible for the nation. The problem of my religion, I deal with in other circumstances" (2003). This message was reiterated numerous times with slight variations. A spokesperson for the Prime Minister's office stated, “As Prime Minster of Canada, he has the moral responsibility to protect the equality between Canadians" (Lunman, 2003a). Jean Chrétien defined his role as protector of minorities within Canada to justify his public position on an issue with which apparently he felt internally conflicted because of his religion.

Prime Minister Martin had the same moral conflicts between religion and his position as Prime Minister of Canada. In his case, his personal conflict surfaced more explicitly (Laghi, 2004). In spite of his reticence, his belief in the Charter as a document 
that cannot be compromised superseded the precepts of his religion. As a result, the primacy of the Charter and the Canadian values it enshrines in the Canadian imagination shaped his approach to the same-sex marriage issue. While on an official visit to India, for example, Martin made constant reference to the fact that same-sex marriage was an equality rights issue. On the trip he stated, "I would point out that we are a country of ethnic and religious minorities.... And the purpose of the Charter of Rights is to protect the minorities, to protect them against the oppression of the majority" (Canadian Press, 2005).

He became so impassioned about rights and his role in protecting them that he stated, "...Am I ready to go into an election to uphold the Charter of Rights against those who would attack it? The answer is certainly yes" (CBC News Online Staff, 2005b). However, this impassioned plea was short-lived and corrected the next day with the following statement: "The role of the prime minister of this country is to protect the rights of the minorities, and protecting the rights of the minorities is certainly a question about which the government of Canada will be prepared to go to the people on" (CBC News Online Staff, 2005b).

Both men managed to negotiate the battles between their personal beliefs to support same-sex marriage and the values upon which those rights are based. In doing so, they reinforced the message promoted by gay and lesbian activists, albeit on a national level. However, their public battle to reconcile their public persona with their personal feelings within a climate of high stakes public contestation over same-sex marriage, especially in the case of Prime Minster Paul Martin, diminished the legitimacy of the position held by same-sex marriage supporters. This public 
reconciliation of both Prime Ministers' inner doubts might also explain the emphasis placed on rights and their roles as the defenders of the Charter of Rights and Freedoms, for it appears that both men chose to drape themselves in the Charter and equality rights in order to deflect national attention from their own personal misgivings about same-sex marriage.

By using a rights-based justification to support same-sex marriage, Liberal supporters simultaneously created a sense of resignation and inevitability regarding same-sex marriage. This discourse of resignation appeared early in the debates. Comments from the House of Commons Committee charged with the task of examining legal options in response to the court decisions were not optimistic. Marlene Jennings, a Liberal member of the House of Commons Standing Committee on Justice and Human Rights, stated that "the federal government has no choice but to widen the definition of who should be considered as married" (CBC News Online Staff, 2003c). As a method to diffuse tension created by court decisions on same-sex marriage, the resignation theme created room for the debates around judicial activism to flourish by backhandedly pinning this situation on the courts and their decisions.

Member of Parliament Richard Marceau from the Bloc Québécois added to this discourse, reportedly stating that the only unanimous position of Committee members was the unacceptability of the present definition of marriage (Tibbets, 2003). This again reveals the reluctance of the Canadian government and its politicians to deal with the situation proactively in that the committee members could not accept the reality of same-sex marriage and propose viable legal or legislative alternatives to the government. Later, Chrétien reiterated a similar message stating, "Same-sex marriage is 
a fact like it or not...Even if the bill is defeated, the law stands.... That's the reality!" (Pannetta, 2003). Resignation, in spite of his public support, exposes the reluctance with which Chrétien chose to deal with the issue of same-sex marriage.

While pushing forward with the landmark legislation, Chrétien's words continued to belie his actions. In another article, he is cited saying, "We don't react with elections in mind. We react to the problems we have" (Pannetta, 2003). Not only was gay and lesbian equality classified as a "problem," but it was also labelled an emergency. He states, "We were faced with an emergency, and we dealt with it that way" (Moore, 2003). These classifications demonstrate the resignation that infused federal government responses to same-sex marriage. Thus, the progress of equality and deconstruction of the third sexual regime was stymied by the conflicting support of both the extension of equality rights and the defence of the nation by the Prime Minister himself.

This point is observed further in an interesting shift that occurred around the issue of rights and protection. Earlier debates coalesced around the right of gays and lesbians to marry. Yet, the decision of the courts moved same-sex marriage debates away from the equality rights of gays and lesbians to the government's duty to protect the religious freedoms of Churches and individuals also guaranteed by the Charter. The protection of religious freedom appears early in the same-sex marriage debates in 2003, when Chrétien reiterated the importance of the freedom of religious groups. The shift in rights protection by those who support same-sex marriage is significant in that it is used as a way to ensure the passage of the legislation and garner support for the evolutionary path of Canadian society. Simultaneously, this discourse mimics those of opponents of 
gay and lesbian marriage outlined earlier in this chapter by supporting the focus on the protection of existing religious freedoms rather than the extension of marriage rights to gays and lesbians. This sequence of events highlights the fact that even when inclusion is granted to an excluded group, such as gays and lesbians, protection of those always included (e.g. religious groups) within the nation will continually be accommodated to protect the nation.

At the same time, the discourse is employed as a tactic to facilitate the inaction and indecision of the Chrétien and Martin governments. This is evident in the 2004 reference made to the Supreme Court of Canada to ensure that the same-sex marriage draft legislation achieved a balance between the individual rights of gays and lesbians and the freedoms of religious groups in Canada. As a result, the Charter's interpretive emphasis on equality rights for gays and lesbians creates significant tensions for other guarantees within the Charter. Even within the article by former Justice Minister Cauchon mentioned above, the tensions are evident. He states,

We also believe in freedom of religion - protecting other's freedom to believe, though we may not follow in that faith. Both these fundamental principles are reflected in the Charter - and the government believes that they are both fully reflected in its draft bill on marriage (Cauchon, 2003).

The discussion of religious freedoms continued in the Martin government with the addition of a fourth question to the reference on the constitutionality of the traditional definition of marriage. This fourth question concerning marriage's constitutionality ${ }^{16}$, criticized by the courts, was ultimately left unanswered. The reference, however,

\footnotetext{
${ }^{16}$ Originally, the non-binding Supreme Court reference asked three questions: 1) Whether Parliament has the legal right to define marriage; 2) If the proposed legislation supports the Canadian Charter of Rights and Freedoms; and 3) Whether churches would be protected from having to perform same-sex marriages if it were contrary to their beliefs. The fourth question, added to the reference, questioned whether limiting marriage to a man and a woman was unconstitutional (CBC News Online Staff, 2004b).
} 
allowed for the debate of religious freedoms to overshadow the rights actually being devolved to gays and lesbians. As a result, the Canadian public came to identify samesex marriage with the freedom of religious groups. This modulation of the issue, I contend, successfully moves the debates away from the creation of equality for all Canadian citizens to the maintenance and protection of religious groups that continue to have a role of historical importance within the Canadian nation-state.

In sum, a reliance on values of equality and rights supported a second set of debates around inevitability and resignation and allowed for the shift from the rights of gays and lesbians to marry to the protection of the freedom of religious groups to retain religious marriage as a heterosexual institution that should continue to exclude gays and lesbians. The dependence on these ideological values and constructs of Canadian nationalism, while powerful and resonant amongst the Canadian public, are easily malleable and can be shifted significantly without much effort. As seen above, it is this potential for shift and flux that can easily change messages and societal focus which may continue the third sexual regime's exclusion, and deny belonging to gays and lesbians.

\section{Conclusions}

In this chapter, I presented the arguments for and against same-sex marriage as captured by newspaper reports and supplementary materials from key groups and stakeholders within the universe of political discourse that surrounds same-sex marriage. This method was chosen to capture debates from both the state, society and their intersections. I began the chapter with a brief outline of the sequence of events preceding debates on same-sex marriage. As I demonstrated, relationship recognition 
and the achievement of marriage were central to the goal of relationship recognition within the gay and lesbian movement. In spite of a protracted struggle, positive court decisions in British Columbia, Ontario, and Quebec unleashed a torrent of debate around the issue by granting marriage to gays and lesbians.

The pillars of Canadian society were invoked throughout the debates on samesex marriage. For opponents of same-sex marriage, homosexuality, the institution of marriage and family were drawn upon regularly to support their position. These individuals tapped into the "deviance of homosexuality" and the heterosexual origins of marriage and the traditional family to convince Canadians that same-sex marriage would be detrimental to English Canadian society. Here, the arguments stirred fear over the unknown changes that same-sex marriage might imply for Canada.

To reinforce their positions, opponents of same-sex marriage also delegitimized institutions and legislation, such as the Charter of Rights and Freedoms and the courts, to forward their argument. In this case, these tactics sought to undermine the legitimacy of the Canadian courts with arguments of judicial activism and re-negotiation of the meaning of rights and Canadian values that form the basis of the Charter of Rights and Freedoms. This double pronged strategy shored up a very powerful position that effectively reinforced the status quo.

In contrast, supporters of same-sex marriage conveyed their positions through the use of rights talk, rights, the Charter of Rights and Freedoms, and Canadian values of equality and non-discrimination. These tactics deployed progressive language and ideas designed to deconstruct the third sexual regime. Gay and lesbian activists effectively utilized rights talk to justify same-sex marriage to politicians and Canadians. 
However, rights were employed in different ways with activists conjuring images of a human rights discourses and struggles for equality. On the other hand, politicians used rights within a national context, separate from international of human rights. In both cases, these arguments lent support to the image of inevitability politicians created to encourage English Canadian society's acceptance of change and difference. Nevertheless, rights-based arguments also created room for gay and lesbian equality to be compromised by same-sex marriage supporters in government. In an effort to get marriage "at any cost," politicians relied on a climate of resignation about same-sex marriage within Canadian society, which allowed for the protection of religious freedoms within Canada to take precedence over the right of gays and lesbians to marry. In the next chapter, I complete my analysis of the same-sex marriage debates. I will show how these debates are situated squarely within the third sexual regime and illustrate its incomplete deconstruction, despite the passage of Bill C-38. 


\section{Chapter 5: Interpreting Contestation: Same-Sex Marriage Debates}

\section{Introduction}

In the preceding chapter, I presented a snapshot analysis of the same-sex marriage debates. My goal was to sample the contestation occurring within the universe of political discourse around issues of sexuality in Canada. As I illustrated, supporters and opponents of same-sex marriage employ nationalism's pillars in a variety of ways to influence the opinions of the Canadian public and key decision makers. This chapter completes my analysis of the same-sex marriage debates. My goal is to analyse the incomplete deconstruction of the third sexual regime. I contend that in spite of the actors' deconstruction efforts and legal successes, the third sexual regime continues to marginalize gays and lesbians from belonging within the English Canadian nation through managed integration and democratic homophobia.

As outlined in Chapter Three, throughout the previous two sexual regimes, the English Canadian nation maintained a compulsory heterosexuality through the direct exclusion and regulation of homosexuals. In the current sexual regime, I maintain that deconstruction efforts have replaced exclusion with the managed integration of gays and lesbians. Moreover, democratic homophobia continues to oppress homosexuals while extending privilege to heterosexuals. The project of deconstruction then seems unable to realize the full inclusion some Canadian gays and lesbians seek. As a consequence, I argue that the exclusion of gays and lesbians cannot be corrected by legal or legislative remedies alone. Instead, the role of nationalism must be made to account for its part in the persistence of gay and lesbian marginalization. 
In the following section, I review my interpretation of English Canadian civic nationalism's exclusionary nature. Here, I highlight the key facets of my argument in Chapter Two to aid my analysis of the same-sex marriage debates. Next, I explore the role of nationalism within the same-sex marriage debates. I argue that the use of nationalism within the same-sex marriage debates attempt either to reify or deconstruct the third sexual regime. Finally, I explore the costs of deconstruction for gays and lesbians and the potential for their inclusion within the national community.

\section{(Re-)Defining the Character of Civic Nationalism}

Early in my study, I outlined how civic nationalism, while inclusive, may be an exclusionary force with the power to hold groups and individuals outside of the national community. To demonstrate nationalism's exclusionary potential, I borrowed from the works of Benner (2001), Marx (2003), Vickers (2000; 2002), and Pryke (1998) to propose a framework for analysing the exclusion of gays and lesbians from the national community. The cornerstone of my framework is Benner's idea of the strong national identity. The protection of this national identity often gives rise to "un-civic" and illiberal turns of the state in order to protect the nation. As a result, protecting against threats to the nation's identity will often trump the national rights and values held by individuals or groups to protect the political community.

The work of Anthony Marx examines the method through which unity is sustained - exclusion. As Marx notes, the cohesion of a strong national identity is facilitated by the maintenance of an internal enemy. The characteristics of the internal enemy change and shift over time; however, the "other" or "enemy" designation remains constant throughout their exclusion. This construction of the internal "other" 
defines their marginalization within a political community united through the nation's identity. The fluid and erratic nature of civic nationalism's exclusion, however, raises a purposeful amnesia among included citizens. This state of amnesia allows past struggles to be forgotten while subtle discrimination and differences persist. As such, the marginalization of a minority group within a political community fades as the threat posed to the nation and its national identity wane.

Jill Vickers' race regime framework, from which I have borrowed, offers insight into the creation and reproduction of nationally sanctioned characteristics and attributes valued by citizens through nationalism and national institutions. Successive regimes, founded upon differences of race and sexuality, build upon one another to maintain the exclusion of certain groups/"others" within the national community. The operation of these regimes is made clear using Pryke's analysis. Here, the interconnections of sexual stereotypes, sexuality as a national threat, and sexuality in nation-building reveal the intricacies of the sexual regimes and use of nationalism to maintain the sanctioned exclusion of internal "enemies."

I then illustrated the existence of sexual regimes in Canada and surveyed how sexual regimes create and reproduce a compulsory heterosexuality. Following Pryke's analysis, sexual stereotypes are used by actors within the sexual regime to characterize homosexuals as promiscuous and "deviant" to maintain a "moral" national heterosexual identity. Second, homosexuality is deemed a threat to the compulsory heterosexuality of the nation. Homosexuality, then, is managed and regulated to reduce its potential damage. Finally, homosexuals are denied entry into legitimate nation-building institutions, such as marriage and the traditional family. These points of exclusion and 
regulation demonstrate the experience of gays and lesbians in Canada. Through three distinct sexual regimes, the threat homosexuality was invoked consistently to unite the national community. The final invocation of the homosexual threat in the same-sex marriage debates continues the trend of gay and lesbian marginalization.

\section{Reading the Contestation in the Same-sex Marriage Debates}

In Chapter Four, I focused on the contestation that occurred within the debates on same-sex marriage. I contend that the clash between those for and against same-sex marriage reveals the use of official and popular pillars of nationalism. The popular pillars of nationalism, such as marriage and the traditional family, reify the foundations of the sexual regimes and advance the English Canadian nation's exclusionary status quo. In contrast, the pillars of English Canada's official modern nationalism, such as the Canadian Charter of Rights and Freedoms, offer tools with which to deconstruct the sexual regime in an attempt to diversify the foundations of the nation. As a result, the deployment of nationalism's pillars reveals how actors perceive the nation and exposes the rationales upon which they rely to forward their positions - the maintenance of the sexual regimes or its deconstruction. This trend demonstrates a significant round of restructuring that takes place and adapts the method of exclusion witnessed in the third sexual regime to managed inclusion and democratic homophobia (Day, 2003, 99).

My analysis illustrated how opponents of same-sex marriage rely on the pillars of popular nationalism. Opposition discourses of homosexual "deviance," and the "threat" of homosexuality to the nation, marriage, and family reinforces the reliance on the sexual regime which seeks to exclude gays and lesbians from the institution of marriage. In addition, the criticisms of same-sex marriage opponents attempted to 
delegitimize the pillars of English Canadian official nationalism. This double-pronged approach speaks to the importance of marriage in the minds of these individuals and their vociferous hostility to the extension of marriage rights to gay and lesbian Canadians.

Pryke's analysis, once again, displays the operationalization of the sexual regime within this side of the same-sex marriage debates. For example, the crux of opponent arguments on homosexual deviance supports negative sexual stereotypes of gays and lesbians. In doing so, these sexual stereotypes reinforce "good"/heterosexuality and "bad"/homosexuality. In the context of the same-sex marriage debates, homosexual "deviance" is reconceptualized as just cause for denying gays and lesbians access to marriage rights. This distinguishes the third sexual regime from the previous two which advanced homosexual "deviance" in the form of "perversity," "pathology," and "character weaknesses." But, the new gay and lesbians stereotypes build on those of the previous regimes in order to defend the denial of marriage.

Following Pryke's second analytical point, the threat of homosexuality is not a threat to the nation per se. Instead, homosexuality poses a threat to the nation's bedrock institutions of marriage and the traditional family. As a consequence, this newly reconfigured homosexual threat demands the unity of heterosexuals to protect the national institution of marriage and the family. The resulting discourse forwarded by opposition to same-sex marriage places an overwhelming emphasis on the historical role of heterosexual marriage in the English Canadian nation. Opposition voices, 
therefore, effectively adapted the notion of "threat" to protect the historical meaning of marriage from the modern "threat" of homosexuality and its supporting institutions.

As I demonstrated in Chapter Four, the threat of homosexuality extended beyond gays and lesbians to the "progressive" institutions and tools employed to gain equality rights. Allegations of judicial activism, re-negotiation of equality rights, and efforts to minimize the impact of same-sex marriage legislation, all expose the perceived threat of these modern pillars to the English Canadian nation. Thus, the incorporation of official symbols of English Canadian nationalism into the threat of homosexuality displays the opposition's willingness to delegitimize these symbols when they threaten majority privilege.

Finally, for opponents of same-sex marriage, the acceptance of homosexuality potentially undermines the nation's procreative functions. The protection of the traditional family's legitimacy was based upon its compulsory heterosexual nature. Marriage's extension to same-sex couples is perceived to increase the vulnerability of the traditional family and risks the security of the nation's future generations. Moreover, the imagined legitimacy of the traditional family is undermined further in that same-sex marriage furnishes a new legitimacy to a previously excluded family form - the samesex family. As a result, for opponents to same-sex marriage, the extension of legitimacy to same-sex families condones the contribution of same-sex families to the English Canadian nation's future growth.

In contrast, the tactics used by supporters of same-sex marriage clearly display a belief in the deconstructive potential of rights, the values of non-discrimination, and equality-seeking frameworks. As I demonstrated in Chapter Four, these pillars of 
official English Canadian civic nationalism form the foundation for same-sex marriage arguments. Unlike the opposition voices, supporters of same-sex marriage do not necessarily address the pillars of popular English Canadian nationalism. This omission reveals the limits of the rights talk discourse in that rights talk does not allow for debates to move beyond the legal and legislative realms of the political regime. Throughout Chapter Four, the debates presented focused on the transfer of rights and equality guarantees. Yet, discussions of the fundamental changes required in society to truly create the inclusion and substantive equality desired by Canadian gays and lesbians are never raised. As a result, the limits of rights talk, while effective in gaining formal equality, does little to further the project of deconstruction in terms of substantive issues of identity and belonging.

Nevertheless, rights talk and the pillars of official English Canadian nationalism form a significant portion of supporters' efforts for same-sex marriage. These methods employed by actors to dismantle the third sexual regime attempt to reverse the opposition's efforts to reify the same regime. Within the same-sex marriage debates, the pursuit of gay and lesbian marriage rights undermines the sexual stereotypes presented by opposition groups of gays and lesbians as "promiscuous," "deviant," and "immoral." In contrast, the image of gays and lesbians seeking marriage often relies on the impression of conformity with English Canadian relationship norms. The positive images of married gay and lesbian couples, therefore, are deployed to challenge the negative sexual stereotypes of gays and lesbians throughout Canadian history by portraying gay and lesbian relationships as "unstable," "unloving," and "unequal" to those of heterosexuals. 
These positive images are designed also to undercut the perceived threat posed by homosexuality to the nation. The efforts of activists, in conjunction with their rights talk approach, create a non-threatening image of gays and lesbians who seek (legal) equality within the English Canadian nation-state. The struggles for same-sex marriage demonstrate a willingness to work within the existing political regime to gain inclusion within the Canadian nation-state peacefully. Moreover, their "respectable" lobby efforts centred on the rights and modern values of official English Canadian nationalism illustrate their acceptance of Canada's democratic system. As a result, Canadian gays and lesbians, along with their supporters, recognize that both their right to equality and the guarantee of freedoms may co-exist.

Finally, supporters insist that the inclusion of homosexuality into the fold of the nation's accepted sexualities permits the contribution of gays and lesbians to the nationbuilding project. The extension of same-sex marriage rights "completes" the struggles for relationship recognition. Once the formal equality of same-sex relationships is acknowledged by governments and Canadians alike, the alleged threat of homosexuals to the nation's future will be reversed with their relationships and families legitimately received within the English Canadian nation.

The operation of the third sexual regime becomes exceeding clear with the use of Pryke's analysis. In addition, the role of nationalism is exposed within the same-sex marriage debates. Opponents of same-sex marriage, continuing the previous practices of the first two sexual regimes, employed the third sexual regime to contest the pattern of homosexual acceptance within the contemporary English Canadian nation. Competing messages regarding sexual stereotypes, the threat of homosexuality to the nation, and 
the extension of marriage to gays and lesbians intensifies the climate of heightened debate witnessed in the same-sex marriage debates. The resulting contestation from the deployment of nationalism by supporters and opponents of same-sex marriage reveals the incomplete deconstruction of the third sexual regime. While actors work to dismantle the third sexual regime, others adapt their tactics to reify its presence within the English Canadian nation. Yet, all the while, gays and lesbians, particularly those who continue to reject the nation's requirement of a "non-threatening" homosexuality for integration, continue to experience exclusion and social marginalization within the English Canadian nation, an exclusion that I believe did not end with the passage of Bill C-38.

\section{The Societal Costs of Deconstruction}

I contend that the third regime continues to influence the plight of Canadian gays and lesbians. Using Pryke's analysis, the contestation within the same-sex marriage debates reveals the use and role of nationalism in perpetuating the sexual regime in spite of concerted deconstruction efforts. The struggles for inclusion by gays and lesbians and the protection of English Canadian nation by conservative forces leads me to conclude that the costs of deconstruction are quite significant for both gays and lesbians and the English Canadian nation. In this section, I explore the societal costs of deconstruction within the context of my broader theoretical discussion of English Canadian civic nationalism.

Above, I highlighted my definition of English Canadian civic nationalism and civic nationalism more broadly. I argue that the deconstruction of the third sexual regime gave rise to the substitution of direct exclusion with a process of managed 
integration and democratic homophobia by the English Canadian nation-state (Day, 1999, 99). The history of gay and lesbians struggles for relationship recognition, equality, and belonging within the national community offer evidence of this point. Although managed integration promises equality, the formal nature of that equality must not be overlooked. The managed integration offered to gays and lesbians through legislation does not necessarily lead to substantive equality. Moreover, the inability to truly dislodge the heterosexual foundations of the nation deprives the English Canadian national community of the chance to fully experience an inclusive society which values diversity and difference.

Falling under the auspices of civic nationalism's regime, managed integration of gays and lesbians fails to offer true equality within the same-sex marriage debates. Instead, homosexuals are subjected to a forced and reluctant inclusion by members of the national community who continue to see a homosexual "other". For example, gays and lesbians remain internal enemies of the state. Despite the passage of Bill-C38, the construction of the gay and/or lesbian "other" still resonates among the Canadian public. If anything, the extension of same-sex marriage rights increases this distinction with the creation of "same-sex marriage," rather than the extension of marriage. This continued "other-ing" of gays and lesbians forms a significant part of the modern English Canadian civic nationalism framework. The use of rights talk to secure these "rights" and "equality" do not remove the classification of "other" or "different". Rather, rights talk and equality-seeking frameworks advanced by official English Canadian civic nationalism reifies difference and, as such, the construction of "other" or 
former internal "enemy" persists within even modern civic nationalism despite the pursuit of sameness and equality.

The "other's" threat and additional equality claims on the political community remain intact despite "inclusive" shifts in values. This practice reflects the institution of democratic homophobia within the third sexual regime. Like democratic racism, democratic homophobia continues the trend of homosexual oppression and sustains the nation's compulsory heterosexuality through protection and maintenance of the homosexual "other." Within the third sexual regime, managed integration protects the included groups of the political regime and trumps the rights of gays and lesbians seeking the extension of marriage rights. This is evident in the discourse around the shift in the same-sex marriage debates from the marriage rights of gays and lesbians to the protection of religious freedoms. Interestingly, this debate shift was acknowledged and condoned by both supporters and opposition alike. Consequently, this confirms Benner's assertion that threats will necessarily trump the rights of the individual to protect the political community. In the context of same-sex marriage, therefore, the right to marry by the "other" was superseded by need to protect the religious groups, who have played a pivotal role in the English Canadian nation.

As discussed in Chapter Two, the strong identity is maintained through the exclusion of certain groups to unite the majority. In the case of same-sex marriage, the continued exclusion of gays and lesbians from religious marriage unites the religious groups of the Canadian nation that were fundamental to its survival and perseverance. As Anthony Marx observes, faith and religion are highly politicized, and necessary for nation- and state-building (Marx, 2003, 26). Thus, the maintenance of a strong identity 
in contemporary times depends on historic allegiances with religious groups. Consequently, despite the values of equality, these relationships remain the priority of the English Canadian nation. In protecting the nation's interests, the Canadian nationstate continues to rely on the exclusionary sexual regime for protection.

The express purpose of the same-sex marriage debate, the extension of marriage rights to gays and lesbians, therefore, becomes subject to the purposeful amnesia. Here, the struggles for inclusion by gays and lesbians are forgotten to ensure that the exclusionary protection of religious groups to discriminate and refuse marriage rights are protected. The passage of Bill C-38, while a step in the equality-seeking struggles of gays and lesbians, does not necessarily advance gay and lesbian belonging within the English Canadian nation. Rather, these debates and the extension of marriage rights forward the managed integration of Canadian gays and lesbians. As such, the deconstruction of the third sexual regime does not provide sufficiently fertile ground for the seeds of true substantive equality and belonging to flourish.

\section{Conclusion}

In summary, the contestation and positions forwarded by those for and against same-sex marriage expose the incomplete deconstruction of the third sexual regime. For those against same-sex marriage, popular pillars of English Canadian civic nationalism are deployed to reify the third sexual regime. In addition, efforts to delegitimize the pillars of official English Canadian nationalism are also utilized. This comprehensive approach by the opposition thwarts the efforts of supporters and sparks the contestation witnessed in the same-sex marriage debates. 
In contrast, supporters rely solely on the official pillars of English Canadian nationalism. As such, they fall prey to the limits of rights talk and the tool of deconstruction. As I demonstrated, rights talk is inspired by the logic that legal remedies can modernize societal norms and values. The same-sex marriage debates, however, reveal that rights talk does not engage the (heterosexual) foundations of the nation. As a result, the project of deconstruction remains unable to transform effectively the heterosexuality upon which the nation relies.

The same-sex marriage debates, therefore, expose the cause for the ongoing marginalization of gay and lesbians from the national community. While deconstruction continues, the exclusion of gays and lesbians also will continue through a process of managed integration and democratic homophobia. Here, gay and lesbian Canadians' inclusion may be extended through the legal guarantees present in the Charter. Their sexuality and relationships, however, maintain their "other-ed" status. Moreover, the rights and "inclusion" gained may be "democratically" reversed if the political community becomes threatened. As such, gays and lesbians do not gain belonging; they receive formal equality and tolerance from supporters and resigned opponents. And, the English Canadian nation simultaneously is denied an opportunity to expand its foundations to truly realize and acknowledge the diversity and difference that exists within its borders. 


\section{Conclusion: Gay and Lesbian Inclusion and Sexual Regimes Overview of the Study}

My thesis began with the assertion that the relationship between nationalism and sexuality is complex, ill-defined and relatively unexplored within both fields of inquiry. As a consequence, I addressed this lacuna with a study of the relationship between English Canadian civic nationalism and homosexuality. Through this thesis, I argue that English Canadian civic nationalism plays a role in the continued discrimination and marginalization experienced by gay and lesbian Canadians. In contrast to much of the existing literature on Canadian gay and lesbian activism, I contend that nationalism contributes to the ongoing denial of equality and acceptance to gays and lesbians within the Canadian national community. While rights- and equality-seeking frameworks succeed in extending formal equality for gays and lesbians, sexual regimes impede the progression to substantive equality assumed to flow from legal guarantees.

In Chapter Two, I acknowledged that while civic nationalisms contain within them both inclusive and exclusive potential, this thesis concentrates on the exclusionary tendencies of English Canada's civic nationalism. Borrowing from the works of Erica Benner and Anthony Marx, I illustrated the potential exclusion that occurs within civic nationalisms when an internal other is maintained. In the Canadian context, I drew from literature on women and race minorities to demonstrate the exclusion experienced by these groups through English Canadian civic nationalism. I then extended this argument to include homosexuality as a ground for exclusion from the nation. I proposed a framework for analyzing sexual regimes which contribute to the exclusion of homosexuals within the nation-state. Borrowing from Pryke's analysis, my 
approach to sexual regimes first identifies the regimes and then explores their institutionalization within a nation-state.

In Chapter Three, I surveyed the three sexual regimes that marked Canada's history. These regimes began with European missionary contact and continue to exert their exclusionary forces to this very day. In my analysis of the first two regimes, I demonstrated the regulation of homosexuality and the national promotion of heterosexuality through regulation. Unlike the first two sexual regimes, however, the current sexual regime is currently undergoing deconstruction. The implementation of a modern, official Canadian nationalism with pillars of equality, non-discrimination, and democracy challenges the earlier overtly-condoned marginalization of gays and lesbians within Canadian society. The deconstruction, however, is incomplete in that despite changes in official nationalism, popular nationalism has expanded only to include "acceptable" homosexuals that mimic heterosexual relationships or assume a "morally respectable" or closeted homosexual lifestyle. As I note, this reflects the insights of Walby with respect to rounds of restructuring which may create modernizing change but still result in ongoing exclusion of homosexual citizens.

To demonstrate the unfinished deconstruction of the third sexual regime, I offered my snapshot case study of the same-sex marriage debates in Chapters Four and Five. Here, I focused solely on the third sexual regime and the contestation over samesex marriage within the universe of political discourse around sexuality in both its official and popular manifestations. Analysis of the debates on same-sex marriage revealed the use of contemporary English Canadian civic nationalism's by those opposed to same-sex marriage in an effort to perpetuate sexual stereotypes, portray 
homosexuality as a threat to the nation, and sanction heterosexuality as the sole sexuality that contributes appropriately to nation-building and family creation. My analysis confirmed the partial deconstruction of the third sexual regime; I believe that much work remains to create a truly inclusive English Canadian civic nationalism that moves beyond tolerance towards full acceptance and the celebration of sexual diversity.

\section{Key findings of the Study}

My thesis on the relationship between sexuality and English Canadian civic nationalism has led to the following key findings.

\section{Nationalism has exclusionary tendencies that can work to maintain a compulsory heterosexuality through sexual regimes.}

This thesis explores civic nationalism's exclusionary potential and power. Civic nationalism, while inclusive, can employ exclusionary rhetoric to exclude and /or forcibly assimilate marginalized populations in order to ensure the survival of the nation-state. In order to accomplish this task, nationalisms may rely on exclusion and the maintenance of internal enemies to secure the future of the political community. In the case of sexuality, sexual regimes, using both state institutions and ideologies can function to marginalize gays, lesbians, and other sexual minorities to keep the nation's compulsory heterosexuality intact. Sexual regimes operate within the nation through the promotion of heterosexuality and the delegitimization of alternate sexualities within the nation-state. Using Pryke's analysis, I identified evidence of this process in my historical overview of Canada's three sexual regimes. 


\section{Sexual regimes still exist within the Canadian nation-state and can deny Canadian lesbians and gays equality and belonging within the Canadian national community.}

Although many gays and lesbians in Canada trust that belonging flows from legal guarantees and rights, this thesis has demonstrated that English Canadian civic nationalism's sexual regime continues to exert its exclusionary power through actors, state institutions and ideologies that preserve the status quo and thwart substantive equality gains. This ongoing contestation results from the incomplete deconstruction of the third sexual regime. As my case study demonstrates, the third sexual regime remains influential because opponents of gay and lesbian equality continue to reify the third sexual regime through sexual stereotypes, and accusations of the ongoing homosexual threat to the nation and its nation-building institutions. Consequently, the contestation that distinguishes the third regime provides evidence of the third regime's continued viability. In contrast to the preceding two sexual regimes, the third sexual regime excludes through the managed inclusion and integration of certain segments of marginalized minorities (Day, 1999, 99). Moreover, these observations cast doubt on the eventual deconstruction of this sexual regime and the creation of an English Canadian nation inclusive of all sexual minorities.

\section{Gay and lesbian inclusion is partial because of the English Canadian nation's heterosexual foundations.}

Despite the passage of same-sex marriage legislation, I posit that the English Canadian nation will only include certain gays and lesbians within the national community. This limitation to acceptance is due to the persistence of the nation's 
foundations which rely upon the compulsory heterosexuality enforced through nationalism's sexual regimes. As a result, the individuals integrated into the national community are those deemed to be non-threatening to the heterosexual norm as reinforced by nationalism and nation-building projects. As a consequence, gays and lesbians who adopt heterosexual relationship models, a closeted homosexual lifestyle, or a "publicly and morally acceptable" homosexual lifestyle, will gain inclusion within the national community. Those lesbian and gay Canadians who do not meet the conditions for inclusion will continue to be marginalized. Thus, the fear of "good" and "bad" homosexuals becomes a self-fulfilling prophecy with the extension of inclusion to certain gays and lesbians according to the terms of the sexual regime.

\section{Nationalism is a tool all social movements must recognize and acknowledge.}

The conventional, popular depiction of civic nationalism as inherently altruistic is challenged by many scholars who recognize the exclusionary potential of all nationalisms. Nationalisms have the power to delimit and define the characteristics of its ideal citizen in the interests of the nation's survival. As a result, social movements must acknowledge the role nationalism plays in their activism and equality- and rights seeking efforts. As the case study on same-sex marriage debates illustrates, opponents of same-sex marriage utilized nationalism to its fullest extent to create opposition to same-sex marriage.. On the other hand, supporters of same-sex marriage situated their arguments in the language of the modern pillars of state-directed nationalism. In relying on English Canadian nationalism in this way, supporters of same-sex marriage underestimated popular nationalism's role in the maintenance of a heterosexual Canadian nation-state through the sexual regime. The result of this underestimation was 
the discourse shift to focus on the religious freedoms of the church rather than gay and lesbian equality. As a result, new social movements should revisit nationalism's influence in past theorization and activism ${ }^{17}$ in order to strategically plan future actions and tactics that seek to redress both the legislative and social barriers it exerts. Such critical assessments of the historical and present usages of nationalism's language, I believe, are critical in unlocking the desired national inclusion sought by gays and lesbians and other marginalized groups within Canadian society.

\section{Limitations of this Study}

I limited the focus of this study to gays and lesbians. This was done in full recognition of the diverse sexualities which exist in the English Canadian nation, but was a result of the limits (time and resources) of this present research project and the same-sex marriage debates snapshot analysis in my study. Sexual regimes exclude all sexual minorities that do not conform to the heterosexual "norm." I recognize that all bisexual, transgendered, transsexual, two-spirited, inter-sexed, queer, or queeridentified individuals are subject to the sexual regimes exclusionary influence of sexual regimes, but this thesis did not attempt to address their respective struggles for inclusion and full acceptance beyond toleration. Instead, I present this thesis as representative of these struggles while respecting their intricacies and calling for further research on their experiences.

For the purposes of this preliminary study, I concentrated on the sexual regime as separate from the gender regime. Throughout this thesis, I have acknowledged the

\footnotetext{
${ }^{17}$ Pauline Rankin (2000) explores the uses of nationalism in early lesbian activism which resulted in the creation of the Lesbian Nation and later, Queer Nation. As such, I believe that gay and lesbian activists should revisit these nationalist moments in our history to reconconceptualize current approaches to equality-seeking efforts with the English Canadian nation.
} 
fact that sexual regimes are gendered and therefore create different experiences of exclusion for lesbians than for gay men. This is due in large part to the differing levels of perceived threat from gays as opposed to lesbians posed to the nation and the fact that feminist scholarship has long demonstrated irrefutably that the relationship of women to their states differs profoundly from that of men (Andrew, 1984). Women, for example, are vital to the nation for their reproductive capacity. As such, the regulation and exclusion of their sexuality is distinct from than that of gay men. These differences continue to this day, but have been altered by the modernization of Canadian society, including the impact of the women's movement.

In addition, my case study on same-sex marriage is limited in that it precludes much of the debate after March 2005. As a result, the important debates during and after the passage of Bill C-38 are not included within this study and, consequently, I exclude much of the contentious debates and arguments used to protect the nation from the passage of this legislation. Despite this limitation, I am confident that my project would be consistent had I included these additional debates. Also, I recognize that the sources utilized are by no means exhaustive; however, the sources chosen do provide a representative overview of the debates and issues central to this study. In future, a comprehensive review of government, non-governmental, key stakeholder documents, and interviews could provide deeper insight into the operation of Canada's sexual regimes within the context of same-sex marriage contestation.

Finally, my study is limited by the lack of primary and secondary literature that treats the intersection between nationalism and sexuality. As such, my study attempts to address this void without the benefit of a body of scholarly literature. Because of this, I 
used works within each of the fields of inquiries to produce a study that I feel responds to Pryke's concerns regarding the lack of research exploring historical antagonisms between nationalism and sexuality. Despite its limitations, I believe this work contributes further to understanding the role of nationalist discourse in both its official and popular forms in the exclusion currently experienced by Canadian gays and lesbians.

\section{Further Research}

In addition to exploring the relationship between nationalism and sexuality in Canada, this thesis presents a new perspective for unearthing and understanding the role of nationalism in Canadian identity-based politics. I maintain there is significant potential in using nationalism as a lens through which to read and understand the successes and failures of the activism of minority groups in Canada. Although many assume nationalism to be benign, my thesis demonstrates that the impact of nationalism can be underestimated. The discourses that official and popular nationalism employ to reify the nation's status quo affects the mobilization and potential results of equality and rights-seeking frameworks. With the achievement of formal equality, in this case Bill C38, I believe that the activism of gays and lesbians must now emphasize the values and promises of belonging within the national community with a focus toward exposing the invisible barriers embedded within some forms of civic nationalism to preclude substantive equality.

Consequently, these observations highlight the need for further research that focuses on the role of nationalist discourses, both official and popular. The character of English Canadian civic nationalism has led to a concentration on rights and equality- 
seeking frameworks by Canada's marginalized communities, not just gays and lesbians, and the scholars that study these communities. Activism by women, gays and lesbians and race minorities has centered on gaining legal equality. In some cases, rights and equality seeking were very successful. In other, such as gay and lesbian activism, belonging beyond legal rights remains illusive. Further study of nationalism may better reveal the exclusionary tendencies with respect to gender, sexuality, race that still mark English Canadian civic nationalism. Such research may also provide the movements around these identities with greater insight into their historical relationship with nationalism and helps shape their future mobilizations. In the end, such research can only increase our understanding of nationalism's power within specific societal contexts and facilitate the possibility of true inclusivity for those who continue to find themselves on the margins of the nation. 


\section{Bibliography}

(2003). "Chrétien supports gay marriage despite Vatican." Retrieved August, 8, 2003, from www planetout com/news/.

Adam, B. (1999). Moral Regulation and Disintegration of the Canadian State. The Global Emergence of Gay and Lesbian Politics: National Imprints of a Worldwide Movement. B. Adam, J. W. Duyvendak and A. Krouwel. Philadelphia, PA, Temple University Press.

Ambrozic, A., Cardinal (2005). An open letter: Why rush on same-sex marriage? Globe and Mail. Toronto: 19.

Andrew, C. (1984). "Women and the Welfare State." Canadian Journal of Political Science 27(4): 667-683.

Arnup, K. (2001). Close Personal Relationships Between Adults: 100 Years of Marriage in Canada. Law Commission of Canada. Ottawa.

Benner, E. (2001). "Is there a core national doctrine?" Nations and Nationalism 7(2): 155-174.

Blackwell, T. (2005). Most want referendum. National Post. Don Mills: 1.

Brown, J. (2003a). "'Gutless' Chrétien hiding behind courts on gay rights, says Alliance." Retrieved August 27, 2003, from www.canada.com/.

Brown, J. (2003b). "Same-sex marriage sparks renewed debate over 'judicial activism'." Retrieved August 25, 2003, from www.canada.com.

Canadian Press. (2003a). "Eves wades into same-sex debate." Retrieved August 27, 2003, from www.globeandmail.com.

Canadian Press. (2003b). "N.B. refuses to recognize same-sex marriages." Retrieved July 24, 2003, from www. theglobeandmail.com.

Canadian Press. (2005, January 18). "Martin runs into same-sex debate in India." Retrieved January 19, 2005, from www.globeandmail.com/servlet/story/RTGAM 20051018.wmart0118/.

Canadians for Equal Marriage. (2003a). "Canadian Alliance Loses Latest Political Game to Oppose Same-sex Marriage." Retrieved April 9, 2005, from www. equal-marriage. ca/resouce.php?id=16.

Canadians for Equal Marriage. (2003b). "Message to the New Government: Don't Try to Deny Same-sex Couples Access to Marriage." Retrieved April 9, 2005, from www equal-marriage. ca/resource.php?id=49.

Cannon, M. (1998). "The Regulation of First Nations Sexuality." The Canadian Journal of Native Studies 18(1): 1-18.

Castle, A. D. (2003). "Upholding Rights - Let's Not Forget the Kids." Retrieved March 2, 2005, from www. defendmarriagecanada.org/uficanada/upholdingrights.html.

Cauchon, M. (2003). "Martin Cauchon." Retrieved August 25, 2003, from www.globeandmail.com/servlet/story/RTGAM.20030819.wcauchon0819/.

CBC News Online Staff. (2003a). "Liberals want same-sex legislation tabled in Commons this fall." Retrieved August 22, 2003, from www.cbc.ca/news/.

CBC News Online Staff. (2003b, June 18). "Ottawa will not appeal gay marriage rulings." Retrieved June 18, 2003, from www.cbc.ca/news/. 
CBC News Online Staff. (2003c, May 10). "Split evident among MPs on gay marriage." Retrieved May 11, 2003, from www.cbc.ca/news.

CBC News Online Staff. (2003d). "Unanimity escapes NDP on the same-sex issue." Retrieved September 4, 2003, from www.cbc.ca/news/.

CBC News Online Staff. (2004a, December 14). "Klein continues to turn up heat on same-sex issue." Retrieved December 15, 2004, from www.cbc.ca.news.

CBC News Online Staff. (2004b). "Supreme Court OK's same-sex marriage." Retrieved December 12, 2004, from www.cbc.ca/news.

CBC News Online Staff. (2005a, January 16). "Calgary bishop wants government to act against gays." Retrieved January 17, 2005, from www.cbc.ca/news.

CBC News Online Staff. (2005b, January 21). "Martin would go to polls over same-sex marriage." Retrieved January 24, 2005, from www.cbc.ca/news.

Clark, C. (2003). "Tory Leader wants Ottawa to get out of marriage." Retrieved August 14, 2003, from www.globeandmail.com/servlet/story/RTGAM20030814.wmackay0813/.

Clark, C. (2004). "Prime Minister rejects same-sex referendum." Retrieved December 13,2004 , from www.globeandmail.com/servlet/story/RTGAM. 20041213.wxsamesex1213/.

Clark, C. and K. Lunman. (2003). "48 Liberal line up against same-sex marriage." Retrieved August 8, 2003, from www globeandmail.com.

Clemenger, B. (2003). "Keep Marriage Heterosexual." Retrieved March 2, 2005, from www.christianity.ca/news/social-issues/2003/09.002.htm!.

Couture, J., K. Nielsen, et al. (1996). Introduction: Questioning the Civic/Ethnic Dichotomy. Rethinking Nationalism. J. Couture, K. Nielsen and M. Seymour. Calgary, Ab, University of Calgary Press. 22.

Day, R. J. F. (1999). Multiculturalism and the history of Canadian diversity. Toronto, University of Toronto Press.

Defend Marriage Canada. "It's All About Kids." Retrieved March 2, 2005, from www defendmarriagecanada org/uficanada/allaboutkids.html.

Dueck, L. (2004). "Can this Marriage be Saved?" Retrieved March 2, 2005, from www. christianity.ca/family/marriage/2004/10.000 html.

Feldman, O. and C. 1. d. Landtsheer (1998). Politically Speaking: A Worldwide Examination of Language Used in the Public Sphere. Westport, Conn., Praeger.

Gagner, P. (2001). The King's Daughters and Founding Mothers: the Filles du Roi, 1663-1673. Pawtucket, R.I., Quintin Publications.

Galloway, G. (2005). "Insults dominate gay-marriage debate." Retrieved February 17, 2005 , from www theglobeandmail.com/.

Gentile, P. (1996). Searching for "Miss Civil Service" and Mr. Civil Service:" Gender Anxiety, Beauty Contests and Fruit Machines in the Canadian Civil Service, 1950-1973. School of Canadian Studies. Ottawa, On, Carleton University: 164.

Gentile, P. (2000). 'Government Girls' and 'Ottawa Men': Cold War Management of Gender Relations in the Civil Service. Whose National Security? Canadian State and the Creation of Enemies. G. Kinsman, D. K. Buse and M. Steedman. Toronto, On, Between the Lines. 
Government of Canada (1999). Appendix One: The Constitution Act, 1982. Canadian Politics. A. G. Gagnon and J. Bickerton. Peterborough, Broadview Press: 565581.

Harvey, B. (2004). Family dreams don't come true. The Ottawa Citizen: A.1.Fro.

Henry, F. B., Bishop of Calgary (2005). Pastoral Letter. Calgary, Canadians for Equal Marriage.

Herman, D. (1994). Rights of Passage: Struggles for Lesbian and Gay Legal Equality. Toronto, University of Toronto Press.

Herman, D. and C. Stychin (1995). Legal Inversions: Lesbians, Gay Men, and the Politics of Law. Philadelphia, Temple University Press.

Hurley, M. C. (2003). Sexual Orientation and Legal Rights. P. R. Branch. Ottawa, Library of Parliament: 39.

Hutchinson, J. and A. D. Smith (1994). Nationalism. Oxford; New York, Oxford University Press.

Ignatieff, M. (1994). Blood and Belonging: Journeys into the New Nationalism. Toronto, Penguin.

Jenkins, B. and S. A. Sofos (1996). Nation and Identity in Contemporary Europe. London; New York, Routledge.

Jenson, J. (1989). "Paradigms and Political Discourse: Protective Legislation in France and the United States Before 1914." Canadian Journal of Political Science 22(2): 235-258.

Kinsman, G. (1995). "'Character Weakness' and 'Fruit Machines': Towards an Analysis of the Anti-homosexual Security Campaigns in the Canadian Civil Service." Labour 35(Spring): 131-161.

Kinsman, G. (1996). The Regulation of Desire: Homo and Hetero Sexualities. Montreal, Black Rose Books.

Kinsman, G. (2000). Constructing Gay Men and Lesbians as Security Risks, 1950-70. Whose National Security? Canadian State and the Creation of Enemies. G. Kinsman, D. K. Buse and M. Steedman. Toronto, On, Between the Lines.

Kinsman, G., D. K. Buse, et al. (2000). How the Centre Holds-National Security as an Ideological Practice. Whose National Security? Canadian State and the Creation of Enemies. G. Kinsman, D. K. Buse and M. Steedman. Toronto, On, Between the Lines.

Laghi, B. (2004). "How the PM overcame his doubts." Retrieved December 12, 2004, from www.globeandmail com/servlet/story/RTGAM.20041210.wsame1210/.

Laghi, B. and K. Harding. (2004). "Harper's same-sex plan lacks 'courage', PM says." Retrieved December 17, 2004, from www.globeandmail com/servlet/story/RTGAM.20041216.wmartin 1217/.

Laghi, B., K. Lunman, et al. (2003). "Liberals facing defeat in same-sex free vote." Retrieved August 14, 2003, from www.globeandmail com/servlet/story/RTGAM.20030813.usame0814/.

Lahey, K. A. (1999). Are we 'persons' yet? Law and Sexuality in Canada. Toronto, University of Toronto Press.

Lahey, K. A. and K. G. Alderson (2004). Same-sex Marriage: The Personal and the Political. Toronto, Insomniac Press. 
Lang, S. (1997). Various Kinds of Two-Spirit People: Gender Variance and Homosexuality in Native American Communities. Two-spirit People: Native American Gender Identity, Sexuality, and Spirituality. S. Lang, S.-E. Jacobs and W. Thomas. Urbana, University of Illinois Press: xiii, 331 p.

Lee, J.-A. and L. Cardinal (1998). Hegemonic Nationalism and the Politics of Feminism and Multiculturalism in Canada. Painting the Maple: Essays on Race, Gender, and the Construction of Canada. V. J. Strong-Boag, S. Grace, A. Eisenburg and J. Anderson. Vancouver, UBC Press.

Lunman, K. (2003a). "Chrétien's 'morally grave' error." Retrieved July 31, 2004, from www.globeandmail.com/servlet/story/RTGAM.20030731.uchre0731/.

Lunman, K. (2003b). Tory MP sounds off on gay marriage. Globe and Mail. Toronto: 4.

MacDougall, B. (1999). Queer Judgments: Homosexuality, Expression and the Courts in Canada. Toronto, Ont., University of Toronto Press.

Martin Sr., P. (1993). Citizenship and the People's World. Belonging: The Meaning and Future of Canadian Citizenship. W. Kaplan. Kingston, McGill-Queen's University Press: 64-78.

Marx, A. W. (2003). Faith in Nation: Exclusionary Origins of Nationalism. Oxford; New York, Oxford University Press.

Mazur, P. (2002). "Gay and Lesbian Rights in Canada: A Comparative Study." International Journal of Public Administration 25(1): 45-62.

McClintock, A., A. Mufit, et al., Eds. (1997). Dangerous Liasons: Gender, Nation, and Postcolonial Perspective. Minneapolis, University of Minnesota Press.

Milloy, J. S. (1999). A national crime: the Canadian government and the residential school system, 1879 to 1986 . Winnipeg, University of Manitoba Press.

Moore, O. (2003). "No dilution of same-sex marriage plans: Chrétien." Retrieved August 12, 2003, from www.globeandmail com/servlet/story/RTGAM.20030812.wgayy0812/.

Mosse, G. L. (1985). Nationalism and Sexuality: Respectability and Abnormal Sexuality in Modern Europe. New York, H. Fertig.

Muthadie, L. and A. Dunfield. (2003). "Marriage divides the House." Retrieved October 17, 2003, from www.globeandmail.com/servlet/story/RTGAM.20030916.wsameno/.

Nimijean, R. (2005). "Articulating the 'Canadian Way': Canada and the Political Manipulation of the Canadian Identity." British Journal of Canadian Studies(forthcoming 2005).

Pannetta, A. (2003, August 21, 2003). "Voting against gay marriage won't do anything to stop it, Chrétien tells MPs." Retrieved August 25, 2003, from www canada.com.

Parker, A., M. Russo, et al., Eds. (1992). Nationalisms \& Sexualities. New York, Routledge.

Pryke, S. (1998). "Nationalism and Sexuality: What are the Issues?" Nations and Nationalism 4(4): 529-546.

Rankin, P. (2000). "Sexualities and National Identities: Reimagining Queer Nationalism." Journal of Canadian Studies 35(2): 176-194.

Ratzinger, J., Card. and A. Amato, S.D.B. (2003). "Considerations Regarding Proposals to Give Legal Recognition to Unions Between Homosexual Persons." 
Retrieved March 2, 2005, from www.vatican.va/roman curia/congregations/cfaith/documents/.

Rayside, D. M. (1998). On the Fringe: Gays and Lesbians in Politics. Ithaca, Cornell University Press.

Real Women of Canada. (2005). "Press Release: Medical Considerations About Samesex Marriage." Retrieved April 2, 2005, from www.realwomenca.com/press htm.

Riggins, S. H., Ed. (1997). The Language and Politics of Exclusion: Others in Discourse. London, SAGE Publications.

Ross, B. (1998). A Lesbian Politics of Decolonization. Painting the Maple: Essays on Race, Gender, and the Construction of Canada. V. J. Strong-Boag, S. Grace, A. Eisenburg and J. Anderson. Vancouver, UBC Press.

Rowstow, A. (2003). "Same-sex marriages OK for now." Retrieved June 12, 2004, from www.planetout com/news/.

Sanders, D. (1994). "Constructing Lesbian and Gay Rights." Canadian Journal of Law and Society $9(2): 99-143$.

Smith, M. (1998). "Social Movements and Equality Seeking: The Case of Gay and Lesbian Liberation in Canada." Canadian Journal of Political Science 31(2): 285-309.

Smith, M. (1999). Lesbian and Gay Rights in Canada: Social Movements and Equalityseeking, 1971-1995. Toronto, University of Toronto Press.

Smith, M. (2004). "Segmented Networks: Linguistic Practices in Canadian Gay and Lesbian Rights." Ethnicities 4(1): 99-124.

Somerville, M. (2003). Every child deserves one mom, one dad. The Ottawa Citizen: A.15.

Stasiulis, D. (1999). Relational Positionalities of Nationalisms, Racisms, and Feminisms. Between Woman and Nation: Nationalisms, Transnational Feminisms, and the State. N. Alarcâon, C. Kaplan and M. Moallem. Durham, NC, Duke University Press: 183-218.

Stasiulis, D. and R. Jhappan (1995). The Fractious Politics of a Settler Society. Unsettling Settler Societies: Articulations of Gender, Race, Ethnicity and Class. D. K. Stasiulis and N. Yuval-Davis. London; Thousand Oaks, Calif., Sage: 95131.

Stasiulis, D. and G. Williams (1992). Mapping Racial/Ethnic Hierarchy in the Canadian Social Formation, 1860-1914: An Examination of Selected Federal Policy Debates. Congress of the Social Sciences and Humanities - Canadian Association of Political Science, Ottawa, On.

Strong-Boag, V. J., S. Grace, et al. (1998). Introduction. Painting the Maple: Essays on Race, Gender, and the Construction of Canada. V. J. Strong-Boag, S. Grace, A. Eisenburg and J. Anderson. Vancouver, UBC Press.

Stychin, C. (1995). Equality Rights, Identity Politics, and the Canadian Imagination. Law's Desire: Sexuality and the Limits of Justice. C. Stychin. London; New York, Routledge: ix, $186 \mathrm{p}$.

Stychin, C. (1997). "Queer Nations: Nationalisms, Sexuality, and the Discourse of Rights in Quebec." Feminist Legal Studies 5(1): 3-34. 
Stychin, C. (1998). A Nation by Rights: National Cultures, Sexual Identity Politics, and the Discourses of Rights. Philadelphia, Temple University Press.

Taber, J. (2003a). "Liberals planning revolt on same-sex." Retrieved August 7, 2003, from www. globeandmail.com.

Taber, J. (2003b). "MP Clifford Lincoln." Retrieved August 25, 2003, from www.theglobeandmail.com/servlet/story/RTGAM.20030812.ulinc0821/.

Tibbets, J. (2003). Let gays, lesbians marry! Status quo no longer acceptable, justice committee says in draft document. Kingston Whig-Standard. Kingston: 11.

Vacante, J. (2005). "Writing the History of Sexuality and "National" History in Quebec." Journal of Canadian Studies 35(3): 31-57.

Valverde, M. (1991). The Age of Light, Soap, and Water: Moral Reform in English Canada, 1885-1925. Toronto, McClelland \& Stewart.

Vickers, J. (1992). Where is the discipline in Interdisciplinarity? Papers on Interdisciplinarity, Montreal, Association for Canadian Studies.

Vickers, J. (1997). Thirty-five Years on the Beaver Patrol. Outside the lines: issues in interdisciplinary research. L. Salter and A. M. V. Hearn. Montreal, McGillQueen's University Press: viii, 212 p.

Vickers, J. (2000). The Politics of "Race": Canada, Australia and the United States. Ottawa, Ont., Golden Dog Press.

Vickers, J. (2002). No Place for 'Race'? Why Pluralist Politics Fails to Explain the Politics of 'Race' in 'New Societies'. The Challenge of Cultural Pluralism. S. Brooks. Westport, Conn., Praeger: 15-38.

Vickers, J. and M. de Sève (2000). "Introduction." Journal of Canadian Studies 35(2): 5-34.

Walby, S. (1997). Gender Transformations. London; New York, Routledge.

Warner, T. (2002). Never Going Back: A History of Queer Activism in Canada. Toronto, University of Toronto Press. 